\title{
Testosterone: a vascular hormone in health and disease
}

\author{
Daniel M Kelly ${ }^{1}$ and T Hugh Jones ${ }^{1,2}$ \\ 'Department of Human Metabolism, Medical School, The University of Sheffield, Sheffield S10 2RX, UK \\ ${ }^{2}$ Robert Hague Centre for Diabetes and Endocrinology, Barnsley Hospital NHS Foundation Trust, \\ Gawber Road, Barnsley S75 2EP, UK
}

Correspondence should be addressed to $\mathrm{T} \mathrm{H}$ Jones Email hugh.jones@nhs.net

\begin{abstract}
Coronary heart disease is a leading cause of premature death in men. Epidemiological studies have shown a high prevalence of low serum testosterone levels in men with cardiovascular disease (CVD). Furthermore, a low testosterone level is associated in some but not in all observational studies with an increase in cardiovascular events and mortality. Testosterone has beneficial effects on several cardiovascular risk factors, which include cholesterol, endothelial dysfunction and inflammation: key mediators of atherosclerosis. A bidirectional relationship between low endogenous testosterone levels and concurrent illness complicates attempts to validate causality in this association and potential mechanistic actions are complex. Testosterone is a vasoactive hormone that predominantly has vasodilatory actions on several vascular beds, although some studies have reported conflicting effects. In clinical studies, acute and chronic testosterone administration increases coronary artery diameter and flow, improves cardiac ischaemia and symptoms in men with chronic stable angina and reduces peripheral vascular resistance in chronic heart failure. Although the mechanism of the action of testosterone on vascular tone in vivo is not understood, laboratory research has found that testosterone is an L-calcium channel blocker and induces potassium channel activation in vascular smooth muscle cells. Animal studies have consistently demonstrated that testosterone is atheroprotective, whereas testosterone deficiency promotes the early stages of atherogenesis. The translational effects of testosterone between in vitro animal and human studies, some of which have conflicting effects, will be discussed in this review. We review the evidence for a role of testosterone in vascular health, its therapeutic potential and safety in hypogonadal men with CVD, and some of the possible underlying mechanisms.
\end{abstract}

Journal of Endocrinology

(2013) 217, R47-R71

\section{Introduction}

For many decades, testosterone has been perceived by the medical community to play a role in the development of prostate cancer and cardiovascular disease (CVD), with its potential as a cardiovascular therapeutic agent being generally overlooked. This assumption was largely based upon the observed clinical benefit of androgen deprivation therapy (ADT) in prostate carcinoma patients and the case reports of sudden cardiovascular death among male athletes abusing anabolic steroids (Cohen \& Hickman 1987, Thompson et al. 1989, Sullivan et al. 1998, Denmeade \& Isaacs 2002). However, there is no compelling evidence that testosterone replacement to levels within the normal healthy range contributes adversely to the pathogenesis of CVD (Carson \& Rosano 2011) or 
prostate cancer (Morgentaler \& Schulman 2009), and conversely, recent evidence indicates that testosterone may be beneficial in the management of the commonly associated conditions (e.g. obesity, metabolic syndrome (MetS) and type 2 diabetes mellitus (T2DM)) that are well known to be associated with an increased incidence of CVD.

Atherosclerosis is a complex disease of the arteries characterised by endothelial dysfunction, vascular inflammation and the build-up of lipids within the intima of the vessel wall. Many cardiometabolic risk factors facilitate the development of atherosclerosis, although the precise underlying mechanisms remain disputed. The formation of an atherosclerotic plaque as the disease progresses can lead to stenosis of the artery, reduced blood flow and increased blood pressure as vascular function is further disrupted. Therefore, a negative cycle of metabolic, vascular and inflammatory dysregulation in the vessel wall evolves. The maintenance of vascular tone through a correct response to vasoconstrictive and vasodilatory agents is especially important in the context of atherosclerosis in the coronary circulation. Reduced vasodilatory responses and enhanced vasoconstriction may further restrict haemodynamic flow through atherosclerotic vessels with stenosis, exacerbating clinical symptoms and perpetuating vascular dysfunction, which can also lead to vasospasm and, for example, worsening angina symptoms.

The ageing blood vessel is less able to protect itself from injury induced by diseases such as dyslipidaemia, T2DM and obesity, with a loss of compliance in the aorta and the principal arterial conduits (Franklin et al. 1997). In turn, this loss of compliance is a powerful determinant of cardiovascular risk and the development of atherosclerosis (Blacher et al. 1999). It is also known that ageing is associated with the development of low-grade systemic inflammation (or 'inflammageing'), characterised by raised serum C-reactive protein (CRP) and pro-inflammatory cytokine levels (Bartlett et al. 2012). Importantly, this inflammageing is implicated in the pathogenesis of atherosclerosis as well as T2DM and is associated with increased mortality. Although ageing is associated with an increased incidence of CVD in males and females, $68 \%$ of premature cardiovascular mortality is accounted for by men (http://www.bhf.org.uk/research/heart-statistics. aspx, 21/03/2012). Therefore, as testosterone levels progressively decline in ageing men, and diminished vasoreactivity and vascular inflammation are associated with ageing per se (English et al. 2000a), a vascular role for testosterone in cardiovascular protection has been hypothesised.

The majority of epidemiological studies have found that there is a high prevalence of low testosterone levels in men with coronary heart disease (CHD), and this association exists regardless of the age of the patient (Jones 2010a). In fact, an increase in all-cause and cardiovascular mortality has been correlated with low testosterone levels in population studies (Khaw et al. 2007, Laughlin et al. 2008, Vikan et al. 2009, Ponikowska et al. 2010) and also within a population of men with proven CHD (Malkin et al. 2010). Some evidence now even suggests that low testosterone levels should be considered an independent cardiovascular risk factor (Jones \& Saad 2009 , Jones $2010 a, b)$. The causality of the relationship between low testosterone levels and vascular disease is unclear. Indeed, Araujo et al. (2011) suggest that cardiovascular mortality in such patients is driven by the underlying health status and that a low testosterone level is simply a marker of poor general health. It is likely, however, that a bidirectional effect between decreased testosterone concentrations and disease pathology exists as concomitant cardiovascular risk factors (including inflammation, obesity and insulin resistance) are known to reduce testosterone levels and that testosterone confers beneficial effects on these cardiovascular risk factors (see Kelly \& Jones 2013). A recent prospective populationbased study of elderly Swedish men has demonstrated that high endogenous testosterone levels predict reduced fatal and non-fatal cardiovascular events over a 5-year followup period (Ohlsson et al. 2011). Testosterone levels in the highest quartile were associated with reduced cardiovascular events compared with those in the three combined lower quartiles, which remained after adjustment for traditional risk factors. Although this further indicates a protective influence of testosterone in CVD, a high testosterone level in elderly men may be a sign of good general health and thereby associated with a reduced risk of cardiovascular events.

$\mathrm{ADT}$ for the treatment of prostate cancer increases the risk of CHD, diabetes and cardiovascular death (Keating et al. 2006, Levine et al. 2010, Jones 2011). This supports a key role of testosterone in atheroprotection, noted by a science advisory from the American Heart Association (Levine et al. 2010). In a recent meta-analysis of over 4000 prostate cancer patients from eight randomised trials with ADT, Nguyen et al. (2011) have found no increased risk of cardiovascular death. The patients in these trials, however, were not stratified by pre-existing cardiovascular comorbidity and received a relatively short-duration ADT

Published by Bioscientifica Ltd. 
( $\leq 3$ years) and studies were not specifically designed to reveal a relationship between ADT and cardiovascular morbidity and therefore cannot exclude the possibility of long-term detrimental effects and in-patient subgroups. Achieving a normal physiological testosterone concentration through the administration of testosterone replacement therapy (TRT) has been shown to improve risk factors for atherosclerosis including reducing central adiposity and insulin resistance and improving lipid profiles (in particular, lowering cholesterol), clotting and inflammatory profiles and vascular function (reviewed in Jones \& Saad (2009) and Jones $(2010 a)$ ). The exact mechanism by which testosterone produces these effects is largely unknown. Some studies have reported confounding results, and there is a shortage of long-term placebo-controlled trials. Indeed, the only way to conclusively substantiate a causal relationship between testosterone and cardiovascular morbidity and mortality is to undertake 5-year clinical outcome trials, and a need for such studies is apparent.

Numerous animal studies support an anti-atherogenic action of testosterone in males, whereby castration accelerates aortic plaque build-up in models of atherosclerosis (Bruck et al. 1997, Alexandersen etal. 1999, Nathan et al. 2001, Nettleship et al. 2007a, Bourghardt et al. 2010). Testosterone replacement in these animals significantly diminished plaque formation, indicating a direct role for testosterone in the aetiology of atherogenesis. Despite these indications, testosterone is not routinely monitored in men at cardiovascular risk and the use of testosterone as a cardiovascular therapeutic agent in hypogonadal men remains disputed due to the relatively limited understanding of the underlying mechanisms of action and a lack of large randomised placebo-controlled clinical trials focussing on CVD-related morbidity and mortality.

Another reason for the action of testosterone on cardiovascular function being difficult to define is that androgens may potentially affect cellular function by both genomic and non-genomic mechanisms. Testosterone may signal through its cytoplasmic cognate (androgen receptor (AR)) directly or via $5 \alpha$-reductase conversion to its more potent metabolite, dihydrotestosterone (DHT). Alternatively, testosterone is converted to $17 \beta$-oestradiol $\left(\mathrm{E}_{2}\right)$ by aromatase and subsequently activates the oestrogen receptor (ER), diversifying the potential signalling pathways. Indeed, sex hormone receptors and testosteroneconverting enzymes are expressed in the arterial wall and in cultured vascular cells (Wu \& von Eckardstein 2003). In addition to these genomic mechanisms, testosterone may act via non-classical routes during the cell membrane channel activation and/or in the presence of
G-protein-coupled, agonist-sequestrable receptors that initiate rapid intracellular signalling cascades and transcription-independent signalling (Heinlein \& Chang 2002). The influence of these heterogeneic signalling pathways on cardiovascular function remains to be clarified.

This review focusses on some of the clinical, experimental and mechanistic evidence implicating testosterone as a vascular hormone in cardiovascular disorders.

\section{Testosterone and vascular function}

A negative correlation between testosterone and hypertension has been demonstrated in men (Barrett-Connor \& Khaw 1988, Khaw \& Barrett-Connor 1988, Hughes et al. 1989, Phillips et al. 1993, Simon et al. 1997, Svartberg et al. 2004). In a subpopulation of 206 men from the Baltimore Longitudinal Study of Ageing, serum testosterone levels were proved to be an independent negative predictor for developing arterial stiffness, assessed from the peak systolic and end diastolic diameters of the common carotid artery and simultaneous brachial artery blood pressure (Hougaku et al. 2006). This association remained after adjusting for other risk factors including age, pulse pressure, fasting plasma glucose, BMI and total cholesterol. Similarly, free serum testosterone was negatively correlated with the measures of vascular stiffness in a retrospective, cross-sectional study of older men (Dockery et al. 2003a). This is further supported by the evidence that patients with prostate cancer undergoing ADT develop arterial stiffness within 3 months, as measured by the pulse-wave velocity (Smith et al. 2001, Dockery et al. $2003 b$ ). In addition and potentially offering some explanation to epidemiological findings, low levels of testosterone were related to increased oxidative stress and a reduced antioxidant capacity in men, potentially as a mechanism of disturbed flow due to vascular damage and loss of reactivity (Mancini et al. 2008). Low testosterone levels in men are associated with erectile dysfunction (ED), which in part may be a result of impaired penile blood flow due to diminished vasoreactivity (Yassin \& Saad 2008, Corona et al. 2009). Indeed, ED is predominantly a vascular condition. It is well known that impaired erectile function and CVD are closely related in that ED can be the first clinical manifestation of atherosclerosis often preceding a cardiovascular event by 3-5 years (Jackson 2012). These data may therefore suggest that sub-normal levels of testosterone impact negatively on vascular dynamics and the reactivity of blood vessels.

A number of patient-based studies have investigated the influence of testosterone therapy on vascular reactivity

Published by Bioscientifica Ltd.

Downloaded from Bioscientifica,com at $04 / 26 / 2023$ 03:51:36AM 
in men. As early as the 1940s, the therapeutic use of testosterone was reported to improve angina pectoris in men with coronary artery disease (CAD; Hamm 1942, Lesser 1942, Walker 1942, Stigher \& Tulgan 1943) and show a benefit in intermittent claudication, the clinical manifestation of lower leg peripheral artery disease (Edwards et al. 1939, Walker 1942). Since these early investigations, the majority of clinical studies have demonstrated that testosterone therapy, whether administered chronically or acutely, results in improvements in coronary blood flow and cardiac ischaemia in men with CAD, an effect that is considered to arise from the beneficial modulation of vascular tone (see Table 1). Indeed, the vascular system is a target for direct androgen action and the beneficial effects of TRT on symptoms of angina, blood pressure and ED are also observed and may be due to the vasodilatory actions of testosterone and the restoration of normal vascular function (Khaw \& Barrett-Connor 1988, Corona et al. 2008).

In 1977 in the first randomised controlled trial, weekly injections of testosterone cypionate were shown to decrease the sum of ST-segment changes (representing phase 2 of the cardiac action potential with the elevation or depression of the ST segment being indicative of myocardial ischaemia or injury and CAD) in the electrocardiogram after 4 and 8 weeks of therapy (Jaffe 1977). Our group performed the first randomised, double-blind placebo-controlled trial using testosterone therapy add-on to usual therapy to maintain serum testosterone levels within the normal range (mean increase in total testosterone was $5.2 \mathrm{nmol} / \mathrm{l}$ at 3 months; English et al. 2000b). This study treated men with chronic stable angina independent of the testosterone status for 3 months. It reported that testosterone treatment significantly increased time to $1 \mathrm{~mm}$ ST-segment depression compared with placebo over time (Fig. 1A) and that men with lower testosterone levels had a greater response (Fig. 1B). A further randomised placebo-controlled cross-over study demonstrated an improved ischaemic threshold in men with overt hypogonadism (mean total testosterone was $4.2 \mathrm{nmol} / \mathrm{l}$ ) and chronic stable angina after 1 month of bi-weekly i.m. depot of mixed testosterone esters (Malkin et al. 2004b).

Table 1 Effects of testosterone on coronary blood flow and cardiac ischaemia

\begin{tabular}{|c|c|c|c|c|}
\hline Exposure & Patients (age in years) & $\begin{array}{l}\text { Testosterone } \\
\text { administration }\end{array}$ & Outcome & References \\
\hline \multirow[t]{3}{*}{ Acute } & 13 men with CAD $(61 \pm 11)$ & $\begin{array}{l}\text { Intracoronary infusion } \\
\left(10^{-10}-10^{-7} \mathrm{~mol} / \mathrm{l}\right)\end{array}$ & $\begin{array}{l}\text { Increased coronary artery dilatation } \\
\text { following Ach-induced contraction } \\
\text { and increased coronary blood flow }\end{array}$ & $\begin{array}{l}\text { Webb et al. } \\
\quad(1999 a)\end{array}$ \\
\hline & 14 men with CAD $(57 \pm 2)$ & I.v. $(2300 \mu \mathrm{g} / \mathrm{ml})$ & $\begin{array}{l}\text { Increased time to } 1 \mathrm{~mm} \text { ST-segment } \\
\text { depression }\end{array}$ & $\begin{array}{l}\text { Webb et al. } \\
\qquad(1999 b)\end{array}$ \\
\hline & 14 men with CAD $(58 \pm 4)$ & I.v. $(2.5 \mathrm{mg})$ & $\begin{array}{l}\text { Increased time to } 1 \mathrm{~mm} \text { ST-segment } \\
\text { depression post-exercise; increased } \\
\text { total exercise time - improved } \\
\text { exercise-induced myocardial } \\
\text { ischaemia }\end{array}$ & $\begin{array}{l}\text { Rosano et al. } \\
\quad(1999)\end{array}$ \\
\hline \multirow[t]{5}{*}{ Chronic } & $\begin{array}{l}50 \text { men with abnormal } \\
\text { post-exercise } \\
\text { Electrocardiogram (ECG) (58) }\end{array}$ & $\begin{array}{l}\text { I.m. testosterone } \\
\text { cypionate ( } 4 \text { and } 8 \text { weeks) } \\
\text { ( } 200 \text { mg weekly) }\end{array}$ & $\begin{array}{l}\text { Decreased post-exercise ST-segment } \\
\text { depression }\end{array}$ & Jaffe (1977) \\
\hline & 62 men with CHD & $\begin{array}{l}\text { Oral testosterone } \\
\text { undecanoate (10 weeks) } \\
\text { (120 mg/day for two weeks } \\
\text { then 40mg/day thereafter) }\end{array}$ & $\begin{array}{l}\text { Improved angina pectoris and } \\
\text { myocardial ischaemia in ECG } \\
\text { and Holter }\end{array}$ & $\begin{array}{l}\text { Wu \& Weng } \\
\text { (1993) }\end{array}$ \\
\hline & $\begin{array}{l}46 \text { men with chronic stable } \\
\text { angina and }>70 \% \text { stenosis } \\
\text { of at least one coronary } \\
\text { artery }(62 \pm 2)\end{array}$ & $\begin{array}{l}\text { Transdermal (4 and } 12 \text { weeks) } \\
\text { (5 mg patches/day) }\end{array}$ & $\begin{array}{l}\text { Increased time to post-exercise } 1 \mathrm{~mm} \\
\text { ST-segment depression }\end{array}$ & $\begin{array}{l}\text { English et al. } \\
\qquad(2000 b)\end{array}$ \\
\hline & $\begin{array}{l}10 \text { men with chronic stable } \\
\text { angina and }>70 \% \text { stenosis } \\
\text { of at least one coronary } \\
\text { artery or previous } \mathrm{Ml} \text { with } \\
\text { angina }(60.8 \pm 4.6)\end{array}$ & $\begin{array}{l}\text { I.m. injection mixed } \\
\text { testosterone esters } \\
(12 \text { weeks }) \\
(100 \mathrm{mg} / 2 \text { weeks })\end{array}$ & $\begin{array}{l}\text { Increased time to } 1 \mathrm{~mm} \text { ST-segment } \\
\text { depression post-exercise; reduced } \\
\text { exercise-induced myocardial } \\
\text { ischaemia }\end{array}$ & $\begin{array}{l}\text { Malkin et al. } \\
\qquad(2004 b)\end{array}$ \\
\hline & $\begin{array}{l}13 \text { men with chronic stable } \\
\text { angina }(64.8 \pm 7.0)\end{array}$ & $\begin{array}{l}\text { I.m. testosterone } \\
\text { undecanoate (52 weeks) } \\
\text { (1000 mg/2 weeks) }\end{array}$ & $\begin{array}{l}\text { Increased time to } 1 \mathrm{~mm} \text { ST-segment } \\
\text { depression post-exercise and } \\
\text { increased maximal exercise time; } \\
\text { reduced exercise-induced } \\
\text { myocardial ischaemia }\end{array}$ & $\begin{array}{l}\text { Mathur et al. } \\
\text { (2009) }\end{array}$ \\
\hline
\end{tabular}

http://joe.endocrinology-journals.org DOI: 10.1530/JOE-12-0582
C 2013 Society for Endocrinology Printed in Great Britain
Published by Bioscientifica Ltd. 
A

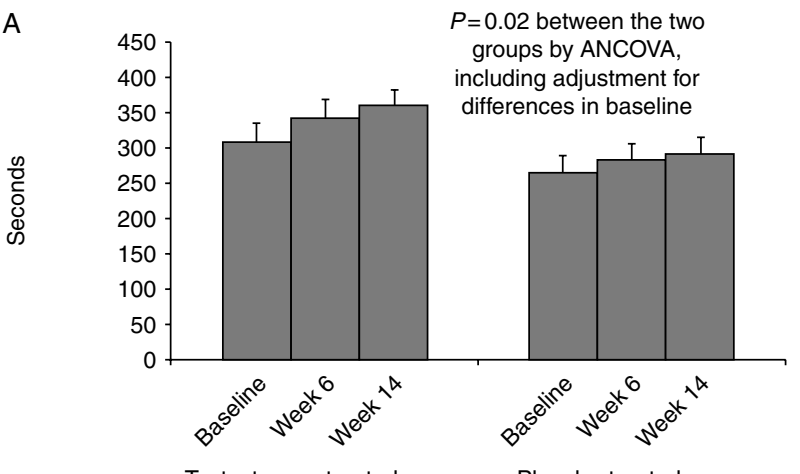

Testosterone-treated group

Placebo-treated group

B

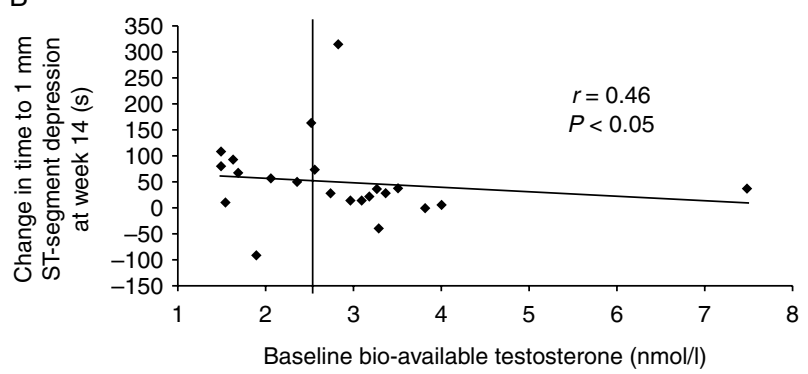

\section{Figure 1}

Testosterone therapy improves angina threshold in men with chronic stable angina. English et al. (2000b) demonstrated that time to $1 \mathrm{~mm}$ ST-segment depression following exercise is greatly increased in the testosterone-treated group compared with the placebo group at baseline and at weeks 6 and 14 (A). In addition, a significant correlation is observed between baseline bioavailable testosterone levels and change in response to exercise-induced cardiac ischaemia (B).

In this study, time to electrocardiogram $1 \mathrm{~mm} \mathrm{ST-segment}$ depression by Bruce protocol exercise testing (a standard measure of exercise-induced ischaemia) was greatly increased (74s) in the treated group compared with the placebo group. Using the same method of assessment, Mathur et al. (2009) also demonstrated that 12 months of testosterone undecanoate treatment reduced exerciseinduced myocardial ischaemia and increased maximal exercise time in hypogonadal men with chronic stable angina. This study is important in showing that there was no decrease in the response (i.e. no tachyphylaxis) of testosterone and that patient benefit persists in the long term.

The acute effects of testosterone treatment on cardiac ischaemia have also been demonstrated with i.v. infusion of high concentrations of testosterone into the coronary blood flow in men with CAD increasing time to exerciseinduced cardiac ischaemia (Rosano et al. 1999, Webb et al. 1999a). Direct infusion of physiological concentrations of testosterone into the right coronary artery of men with CAD rapidly increased the coronary artery diameter and coronary blood flow after pre-constriction with acetylcholine (ACh), consistent with a rapid and direct vasodilatory action (Webb et al. 1999b).

A frequently used method for assessing vascular reactivity is the monitoring of changes in brachial artery diameter by a non-invasive ultrasound assessment as it is considered an accurate and reproducible measurement of endothelium-dependent response to shear stress (Celermajer et al. 1992, Takase et al. 1998). This measure is a marker for increased cardiovascular risk (Kuvin et al. 2001) and correlates with endothelium-dependent coronary and peripheral artery responses (Anderson et al. 1995, Sorensen et al. 1995). Employing this methodology, Ong et al. (2000) demonstrated that high-dose testosterone administered intravenously to men with CAD was associated with a significant increase in brachial artery vasodilation compared with the placebo treatment. Physiological testosterone treatment, however, was reported to have no effect on vascular reactivity. CAD patients in this study had testosterone levels in the low normal range $(11.1 \pm 6.1 \mathrm{nmol} / \mathrm{l})$, which may influence the efficacy of response to physiological testosterone as reported by English et al. (2000b). Pugh et al. (2003) found that the acute administration of testosterone $(60 \mathrm{mg}$ buccal testosterone) to men with moderate chronic cardiac failure in a placebo-controlled trial reduced peripheral vascular resistance and improved the cardiac index, a measure of cardiac output during invasive monitoring. No effect was observed on either pulmonary capillary wedge or pulmonary artery pressure. Again those patients with lower baseline testosterone levels derived the greater benefit from the treatment (see Fig. 2). The effect was maximal after $180 \mathrm{~min}$, which coincided with the maximal testosterone level achieved. The lack of an effect at physiological doses in Ong's study may have also been due to the acute nature (within minutes) of hormone administration, and the authors suggest that chronic exposure to a physiological concentration of testosterone may have a beneficial effect on vascular reactivity in the long term. Indeed, 12-week oral testosterone treatment, which produced plasma free testosterone levels within the physiological range, has been shown to result in a marked increase in both flow- and nitroglycerin-mediated brachial artery vasodilation in men with CAD (Kang et al. 2002).

In contrast to the observed vasodilatory effects of testosterone in men with $\mathrm{CAD}$, prostate carcinoma patients undergoing therapeutic or surgical castration did not demonstrate nitrate-mediated brachial artery vasodilatation (Herman et al. 1997). In fact, increased flow-mediated dilatation was observed in the androgen

Published by Bioscientifica Ltd 

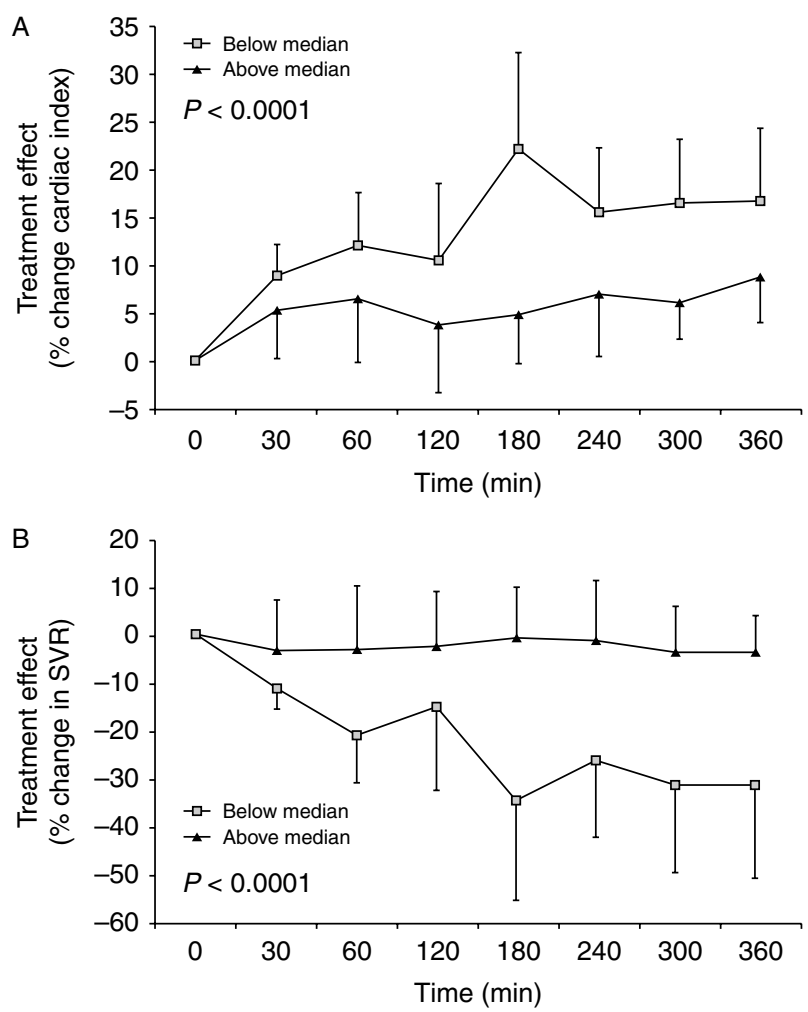

\section{Figure 2}

The vascular response to testosterone is enhanced in patients with the lowest baseline levels. Pugh et al. (2003) indicated that response to testosterone treatment in cardiac index $(A)$ and systemic vascular resistance (B) is significantly greater in subjects with lower endogenous androgens at baseline. The results are presented as patients with bio-available testosterone levels either above or below the median concentration of $4.57 \mathrm{nmol} / \mathrm{l}$ (normal range $2.5-11.9 \mathrm{nmol} / \mathrm{l}$ ).

reduced state groups compared with the controls who were healthy men or patients with non-prostate cancers. Similarly, hypogonadal men without CVD exhibit decreased flow- and nitrate-mediated brachial artery vasodilation or no change following testosterone treatment or transdermal DHT administration (Ly et al. 2001, Kenny et al. 2002, Zitzmann et al. 2002). In addition, the number of CAG repeats in exon one of the AR, thereby reducing sensitivity to testosterone, was associated with endothelium-dependent and -independent brachial artery vasodilatation in healthy men, suggesting an inhibitory effect of AR-mediated testosterone action on vasoreactivity (Zitzmann et al. 2001). Zitzmann et al. (2002) reported that elevated flow-mediated brachial artery dilation in hypogonadal patients was restored to control levels following 3 months of testosterone replacement. These findings were supported by a similar study demonstrating reduced vasodilation after receiving 6 monthly testosterone depot treatment compared with pre-treatment (Sader et al. 2003). However, as these studies of hypogonadal men included only relatively healthy individuals, a positive influence of testosterone treatment may only be observed when vascular reactivity is sufficiently impaired as observed in CAD patients (Jones et al. 2004b). The reduction in vasodilation following testosterone treatment in hypogonadal men may merely represent a restoration of vascular responsiveness rather than a loss of sensitivity to vasodilatory stimuli (Jones et al. 2004b).

Studies mainly in Brattleboro hypertensive rats have suggested that androgens increase tubular sodium and water reabsorption and activate the renin-angiotensin system (Reckelhoff et al. 2005). Testosterone increases extracellular water levels and decreases aldosterone levels, but it has no effect on plasma renin or atrial natriuretic peptide levels, although neither systolic blood pressure nor diastolic blood pressure changed in this study (Johannsson et al. 2005). This has been supported by a recent study that also showed that testosterone reduces aldosterone levels over a 6-month treatment period (Goncharov et al. 2012). The mechanism of this effect was suggested to be due to the activation of the reninangiotensin system or by the increased expression of sodium channels (Johannsson et al. 2005). Animal studies revealed that testosterone replacement in young orchidectomised spontaneously hypertensive rats exacerbates systolic hypertension and reduces pressure natriuresis (Reckelhoff et al. 1998). Clinical studies, however, have revealed either small reductions of $2-3 \mathrm{~mm}$ in diastolic pressure or no significant effects when testosterone is replaced within normal physiological limits in humans (Wang et al. 2004, Jones \& Saad 2009).

\section{Isolated vessels}

Malkin et al. (2006a) demonstrated that testosterone treatment in the high physiological range for 3 months increases the vasoconstrictor response to noradrenaline and reduces dilatation to $\mathrm{ACh}$ and sodium nitroprusside in ex vivo subcutaneous resistance arteries (isolated from gluteal biopsies) of androgen-deficient men compared with pre-treatment. In the same study, a cross-sectional analysis of men with and without heart failure revealed that testosterone caused the vasodilation of pre-constricted subcutaneous resistance vessels in all men, although it was noted that the normal dilating effect of testosterone was augmented in patients with androgen deficiency. Following testosterone treatment, the increased vasodilatory action of testosterone on

Published by Bioscientifica Ltd 
isolated vessels from androgen-deficient men was reduced (Malkin et al. 2006a). Therefore, testosterone alters the responsiveness of subcutaneous resistance arteries to testosterone and also modifies vessel response to other vasoactive agents.

Isolated pulmonary arteries pre-constricted with $\mathrm{U} 46619$, a potent thromboxane mimic, demonstrate vasodilatation upon testosterone exposure in vessels from both male and female human lobectomy samples (Smith et al. 2008). Rowell et al. (2009) extended these investigations to human pulmonary vasculature and demonstrated significant vasodilatation in response to testosterone in isolated pulmonary arteries pre-constricted with potassium chloride. Vasodilatation in response to testosterone at physiological concentrations was only observed in arteries from male subjects and the maximal response at supraphysiological doses was also significantly greater in vessels from the male subjects. Similarly, radial artery isolated from patients undergoing bypass surgery was shown to vasodilate in response to testosterone after pre-contraction with potassium chloride or phenylephrine (Seyrek et al. 2007). The same group had previously found that testosterone relaxes isolated human internal mammary artery pre-contracted with potassium chloride or prostaglandins (Yildiz et al. 2005).

The majority of animal studies support a vasodilatory action of testosterone in several different species (see Table 2). Conversely, alterations in pressor responses to pre-constricted isolated vessels following androgen treatment have also been reported in a few animal studies (Schrör et al. 1994, Farhat et al. 1995, Ceballos et al. 1999, Quan et al. 1999, Teoh et al. 2000a). Ceballos et al. (1999) exposed isolated coronary arteries from male rats to acute physiological concentrations of testosterone and demonstrated an attenuation of the vasodilatation induced by adenosine. Similarly, Teoh et al. (2000b) reported that short-term exposure to physiological levels of testosterone potentiated vasocontractile responses elicited by endothelin-1, 5-hydroxytryptamine, U46619 and potassium chloride in porcine coronary artery rings. However, the gender origin of these isolated vessels was not specified in this study, and consequently it is unknown whether alterations of contractile vasoreactivity are sex dependent. Indeed, Farhat et al. (1995) highlighted further gender differences in contractile responses to both prostaglandin F2 $\alpha$ (PGF2 $\alpha$ ) and potassium chloride in isolated porcine

Table 2 Vasoreactive effects of testosterone on isolated vessels

\begin{tabular}{|c|c|c|c|}
\hline Action & Vessel & Species & References \\
\hline \multirow[t]{19}{*}{ Vasodilatation } & Aorta & Mouse & Jones et al. (2004a) \\
\hline & & Rat & $\begin{array}{l}\text { Perusquía et al. (1996), Crews \& Khalil (1999b), } \\
\text { Honda et al. (1999), Perusquía \& Villalón (1999), } \\
\text { Ding \& Stallone (2001), Unemoto et al. (2007), } \\
\text { Montaño et al. (2008) and Alvarez et al. (2010) }\end{array}$ \\
\hline & Coronary artery & Rat & $\begin{array}{l}\text { English et al. (2000a, 2001, 2002), Pugh et al. (2002) } \\
\text { and Jones et al. (2004a) }\end{array}$ \\
\hline & & Rabbit & Yue et al. (1995) \\
\hline & & Pig & $\begin{array}{l}\text { Crews \& Khalil (1999a), Murphy \& Khalil (1999), } \\
\text { Teoh et al. }(2000 a, b) \text { and Deenadayalu et al. (2001) }\end{array}$ \\
\hline & & Dog & Chou et al. (1996) \\
\hline & & Sheep & Yildirm \& Erol (2011) \\
\hline & Pulmonary artery & Human & Smith et al. (2008) and Rowell et al. (2009) \\
\hline & & Mouse & Jones et al. $(2003 a, b, c)$ \\
\hline & & Rat & English et al. (2001) and Jones et al. (2002) \\
\hline & Pulmonary vein & Human & Rowell et al. (2009) \\
\hline & Mesenteric artery & Human & Jones et al. (2004c) \\
\hline & & Rat & Tep-areenan et al. (2002) and Toot et al. (2012) \\
\hline & Radial artery & Human & Seyrek et al. (2007) \\
\hline & Subcutaneous resistance artery & Human & Malkin et al. (2004a) \\
\hline & Renal afferent arteriole & Mouse & Lu et al. (2012) \\
\hline & Umbilical artery & Human & Perusquía et al. (2007) and Cairrão et al. (2008) \\
\hline & Prostatic small artery & Pig & Navarro-Dorado et al. (2008) \\
\hline & Mammary artery & Human & Yildiz et al. (2005) \\
\hline \multirow[t]{4}{*}{ Vasoconstriction } & Coronary artery & Rat & Ceballos et al. (1999) \\
\hline & & Pig & $\begin{array}{l}\text { Farhat et al. (1995), Quan et al. (1999) } \\
\text { and Teoh et al. (2000b) }\end{array}$ \\
\hline & & Guinea pig & Schrör et al. (1994) \\
\hline & Mesenteric artery & Rat & Toot et al. (2012) \\
\hline
\end{tabular}


coronary arteries following testosterone treatment. Two weeks of s.c. testosterone treatment was associated with an elevation in the vasoconstrictor response in vessels from female animals, but only to potassium chloride in vessels from males. In addition, the testosterone supplementation, while associated with a significant increase in the circulating testosterone levels in female animals, produced a significant decline in circulating levels in male animals, suggesting that the potentially deleterious changes in vascular reactivity may actually have resulted from a reduced circulating testosterone profile in the male animals.

Supraphysiological testosterone levels, which could be considered pharmacological concentrations, are usually required in vitro for the assessment of the effects of hormones on vascular tone. Although this does lead to questions in terms of the physiological relevance of the actions, it is well known that well-established physiological agents such as noradrenaline and Ach that affect vascular tone need to be administered in high $(\mu \mathrm{M})$ dosages (Malkin et al. 2006a). In addition, the effects of vasodilation are studied on potassium chloride-induced vasoconstriction and this also may be a factor as to why high concentrations of ligands are required.

\section{Vascular mechanisms of testosterone}

The underlying cellular and molecular mechanisms by which testosterone modulates vascular reactivity are not fully understood. In most cases, experimental animal studies indicating that testosterone induces vascular relaxation suggest that this takes place via rapid nongenomic mechanisms and that these actions are endothelium independent in a variety of vascular beds including coronary, mesenteric, iliac, renal and femoral arteries (Yue et al. 1995, Chou et al. 1996, Perusquía et al. 1996, Crews \& Khalil 1999a, Murphy \& Khalil 1999, English et al. 2000a, 2001, 2002, Deenadayalu et al. 2001, Ding \& Stallone 2001, Jones et al. 2003a). In contrast, other studies have shown that endothelial denudation significantly inhibits testosterone-mediated vasorelaxation in rat mesenteric artery (Tep-areenan et al. 2002) and isolated human pulmonary artery, with decreased sensitivity to testosterone-induced vasodilation (Rowell et al. 2009). These discrepancies in the role of the endothelium in testosterone-induced vasorelaxation have been considered due to differences in individual study designs with testosterone concentration, acute or chronic exposure, vascular bed investigated and precontractile agent all influencing the outcome. It is also likely, however, that the actions of testosterone on vasoreactivity are partially both endothelium dependent and independent. Indeed, the endothelium-dependent and -independent vasodilatory effects of testosterone were described in studies conducted on canine coronary conductance and resistance arteries in vivo (Chou et al. 1996).

Ion channel modulation The key mechanism underlying the potential vasodilatory actions of testosterone has been proposed by several studies to involve an effect on smooth muscle cell ion channel function, influencing either potassium $\left(\mathrm{K}^{+}\right)$channel opening and/or calcium $\left(\mathrm{Ca}^{2+}\right)$ channel inactivation (Jones et al. 2003b) (Fig. 3). The vasorelaxant effects of testosterone on human umbilical arteries, pre-contracted with serotonin or histamine or potassium chloride, were partially mediated by the activation of both voltage-sensitive $\mathrm{K}^{+}$channels and large-conductance, $\mathrm{Ca}^{2+}$-activated $\mathrm{K}^{+}$channels (Cairrão et al. 2008). This supports earlier animal studies that suggest that testosterone-induced vasorelaxation is mediated predominantly via $\mathrm{K}^{+}$channels in rat mesenteric arterial beds (Tep-areenan et al. 2002), rabbit coronary arteries (Yue et al. 1995) and rat aorta (Ding \& Stallone 2001). In a particularly well-conducted study using patch-clamp recordings, Deenadayalu et al. (2001) identified a specific large-conductance, $\mathrm{Ca}^{2+}$ - and voltageactivated $\mathrm{K}^{+}$channel as the primary effector mediating testosterone-induced relaxation of porcine coronary arteries. This mechanism is supported in the isolated human internal mammary artery, whereby testosteroneinduced vasorelaxations are reduced by the voltagesensitive $\mathrm{K}^{+}$channel inhibitor tetraethylammonium (TEA), with the authors suggesting a $\mathrm{Ca}^{2+}$-activated $\mathrm{K}^{+}$ channel action (Yildiz et al. 2005). The relaxation at low concentrations of testosterone, however, was not altered by other $\mathrm{K}^{+}$channel inhibitors (including ATP-sensitive $\mathrm{K}^{+}$channel inhibitor glibenclamide (GLI) and voltagesensitive $\mathrm{K}^{+}$channel inhibitor 4-aminopyridine (4-AP)). Conversely, the relaxation of isolated human radial artery in response to testosterone was not blocked by TEA, 4-AP or barium chloride and vasodilatation was most effectively reduced with the addition of GLI, suggesting an ATPsensitive $\mathrm{K}^{+}$channel opening action of testosterone (Seyrek et al. 2007). The permissive role of testosterone in vasorelaxation in the erectile tissue is also considered to occur via the induction of acute non-genomic $\mathrm{K}^{+}$ channel activation of vascular smooth muscle cells (VSMCs; Ding \& Stallone 2001).

Several studies have suggested that testosterone primarily inhibits the calcium-dependent elements of

Published by Bioscientifica Ltd 


\section{Figure 3}

Potential mechanisms by which testosterone influences vascular reactivity. Endothelium-independent mechanisms of testosterone are considered to occur primarily via the inhibition of voltage-operated $\mathrm{Ca}^{2+}$ channels (VOCCs) and/or activation of $\mathrm{K}^{+}$channels (KCs) on smooth muscle cells (SMCs). Testosterone shares the same molecular binding site as nifedipine on the $\alpha 1-\mathrm{C}$ subunit of $\mathrm{L}$-type $\mathrm{Ca}^{2+}$ channels to cause channel blockade at physiological concentrations, thus restricting $\mathrm{Ca}^{2+}$ influx and inducing vasodilation (1). Some reports suggest that pharmacological concentrations of testosterone can activate $\mathrm{Ca}^{2+}$ channel opening and induce vasoconstriction through enhanced $\mathrm{Ca}^{2+}$ influx. Alternatively, testosterone activates voltage-operated $\mathrm{K}^{+}$channels and/or large-conductance, $\mathrm{Ca}^{2+}$-activated $\mathrm{K}^{+}$channels, increasing intracellular $\mathrm{K}^{+}$efflux to induce hyperpolarisation and subsequent vasorelaxation (2). Testosterone may also inhibit intracellular $\mathrm{Ca}^{2+}$ influx via store-operated $\mathrm{Ca}^{2+}$ channels (SOCCs) by blocking response to prostaglandin F2 $\alpha$ (PGF2 $\alpha$ ) (3). Endothelium-dependent actions of testosterone may be long-term

vascular contraction by the inactivation of L-type voltage-operated $\mathrm{Ca}^{2+}$ channels to induce the documented vasodilatory effects (Fig. 3). Testosterone abolished the $\mathrm{Ca}^{2+}$-dependent contraction induced by potassium chloride or PGF $2 \alpha$ in male rat coronary arteries (English et al. 2002, Jones et al. 2002) and mouse thoracic aorta (Jones et al. 2003a). Scragg et al. (2004) showed that the vasodilatation response to testosterone occurs selectively via L-type $\mathrm{Ca}^{2+}$ channel inhibition in HEK293 embryonic kidney cells transfected with the $\alpha 1-\mathrm{C}$ subunit that forms the pore of the $\mathrm{L}-\mathrm{Ca}^{2+}$ channel and in the A7r5 rat VSMC line that stably expresses the ${\mathrm{L}-\mathrm{Ca}^{2+}}^{2+}$ channel (Fig. 4a). Indeed, it was further demonstrated in electrophysiological patch-clamp studies that testosterone at increasing genomic and non-genomic effects. Testosterone increases the expression of endothelial nitric oxide synthase (eNOS) and enhances nitric oxide (NO) production (4). Whether these actions are via direct androgen receptor binding, aromatisation to oestradiol and oestrogen receptor activation, or interaction with alternative intracellular signalling pathways remains unknown. Additionally, testosterone treatment has been shown to increase eNOS activity by enhancing phosphorylation potentially via the non-genomic activation of intracellular signalling pathways and $\mathrm{Ca}^{2+}$ influx (5). Increased NO acts on SMCs to induce vasorelaxation by activating cGMP, which in turn activates CGMP-dependent protein kinases (PKG) (6). PKG phosphorylates and activates sarcoplasmic reticulum $\mathrm{Ca}^{2+}$-ATPase (SERCA), which increases the uptake of $\mathrm{Ca}^{2+}$ into the superficial sarcoplasmic reticulum (SR) and therefore decreases global cell $\mathrm{Ca}^{2+}$. PKG also increases $\mathrm{Ca}^{2+}$ release into the submembrane space where the activation of $\mathrm{K}^{+}$channels ensues and PKG may additionally inhibit $\mathrm{Ca}^{2+}$ channel activity directly to cause vasorelaxation. T, testosterone.

physiological concentrations can dose dependently inactivate L-type voltage-operated $\mathrm{Ca}^{2+}$ channels, preventing $\mathrm{Ca}^{2+}$ influx in rat A7r5 VSMCs (Hall et al. 2006; Fig. 4b). When combined with $10 \mathrm{nM}$ testosterone, the treatment of cells with the well-known L-type voltagegated $\mathrm{Ca}^{2+}$ channel blocker nifedipine (a commonly used anti-anginal and anti-hypertensive agent) at its maximally effective dose produced no further suppression of $\mathrm{Ca}^{2+}$ influx, suggesting that testosterone acts at the same site as nifedipine. The addition of pimozide to block T-type voltage-gated channels further reduced the testosteroneinduced inhibition of $\mathrm{Ca}^{2+}$ influx, indicating actions independent of this channel. In another study, Scragg et al. (2007) extended the earlier implications of Hall et al.

Published by Bioscientifica Ltd. 

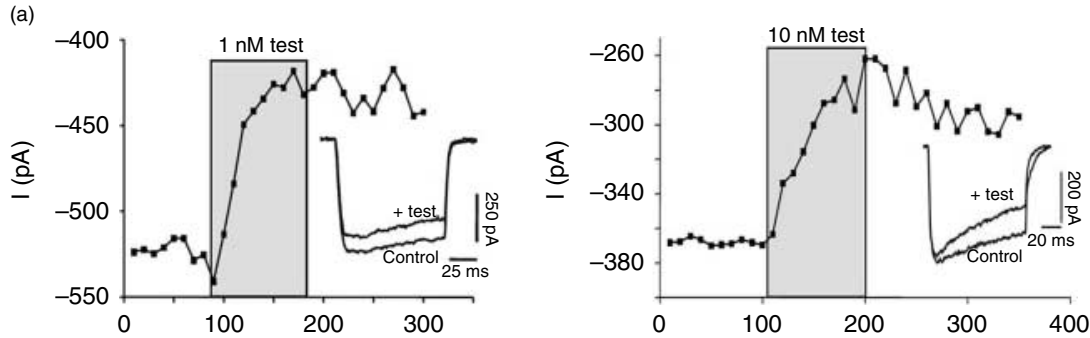

(b)

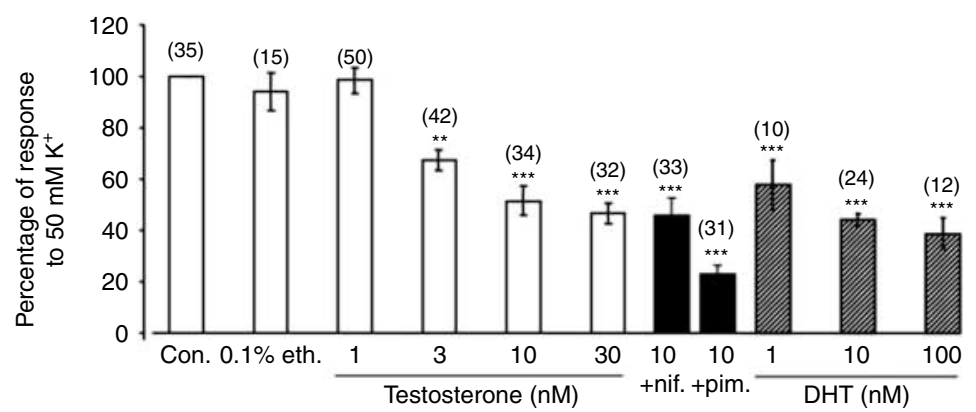

(c)

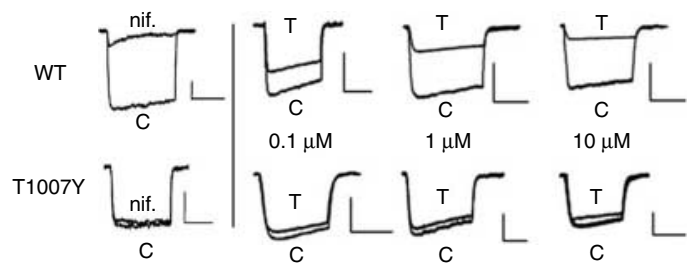

\section{Figure 4}

The vasodilatory actions of testosterone occur via L-type $\mathrm{Ca}^{2+}$ channel modulation. Scragg et al. (2004) demonstrated an inhibitory effect of testosterone over time on $\mathrm{Ca}^{2+}$ channel currents recorded in HEK293 cells stably transfected with the $\alpha 1-C$ subunit of a cloned human cardiovascular L-type $\mathrm{Ca}^{2+}$ channel and rat aortic smooth muscle cell line A7r5 expressing native L-type $\mathrm{Ca}^{2+}$ channels (A). Hall et al. (2006) reported a dosedependent reduction in $\mathrm{K}^{+}$-evoked $\mathrm{Ca}^{2+}$ increase in $\mathrm{A} 7 \mathrm{r} 5$ cells. Nifedipine had no further effects on testosterone response, while pimozide further decreased the response, suggesting an L-type rather than a T-type $\mathrm{Ca}^{2+}$ channel action of testosterone (B). Scragg et al. (2007) further demonstrated that HEK293 cells transfected with the $\alpha 1-\mathrm{C}$ subunit of the L-type $\mathrm{Ca}^{2+}$ channel containing a point mutation (T1007Y) prevent the inhibitory effects of both nifedipine and testosterone on $\mathrm{Ca}^{2+}$ currents compared with cells transfected with the wild-type subunits (C). The authors therefore demonstrate that testosterone acts at the nifedipine-binding site to elicit L-type $\mathrm{Ca}^{2+}$ channel inhibition and subsequent vasodilatation.
(2006) by demonstrating that this rapid action of testosterone acts at the nifedipine-binding site. HEK293 cells transfected with a point mutation in the $\alpha 1-\mathrm{C}$ subunit of the L-type $\mathrm{Ca}^{2+}$ channel almost completely abolished nifedipine sensitivity and rendered the same channel insensitive to testosterone (Scragg et al. 2007; Fig. 4c). These data thereby support a beneficial role for testosterone as an endogenous $\mathrm{L}-\mathrm{Ca}^{2+}$ channel blocker.

An alternative mechanism for the action of testosterone on store-operated $\mathrm{Ca}^{2+}$ channels (SOCCs) has additionally been postulated (Fig. 3). Jones et al. (2003c) clearly demonstrated that the rapid transient increase in intracellular $\mathrm{Ca}^{2+}$ levels responsible for constriction in response to PGF2 $\alpha$ acts via SOCCs in A7r5 cells. The response was resistant to voltage-operated $\mathrm{Ca}^{2+}$ channel blockade, but it was reduced by pre-incubation with SK\&F 96365, a potent SOCC blocker. Testosterone also inhibited the $\mathrm{Ca}^{2+}$ influx response to PGF2 $\alpha$ with a similar efficacy as SK\&F 96365, suggesting an antagonistic effect of testosterone on SOCCs in these cells (Jones et al. 2003c). In a previous study, Jones et al. (2002) used thapsigargin as an indirect activator of SOCCs to investigate the vasodilatory action of testosterone in pulmonary arteries. Thapsigargin inhibits the active uptake of $\mathrm{Ca}^{2+}$ into intracellular stores but leaves the passive release unaffected, thus emptying these stores over time and triggering SOCC opening and $\mathrm{Ca}^{2+}$ influx. Testosterone, however, was unable to induce vasodilatation in thapsigargin pre-constricted vessels, suggesting that there was no effect on SOCCs when intracellular $\mathrm{Ca}^{2+}$ stores were depleted in pulmonary arteries. These differences may be due to the mode of SOCC activation or simply represent

Published by Bioscientifica Ltd. 
alternative mechanisms of action of testosterone in systemic and pulmonary vascular smooth muscle.

Nitric oxide In addition to the well-documented ion channel modulation, testosterone can also influence endothelial function through the modulation of nitric oxide (NO) release (Miller \& Mulvagh 2007; Fig. 3). Testosterone is metabolised directly to $\mathrm{E}_{2}$ by aromatase, which is well known to stimulate NO release. NO is a potent vasodilator that can be synthesised by NO synthase (NOS) and is released by the vascular endothelium, among other tissues, and NO-induced vasodilation is often therapeutically targeted in hypertension and angina (Miller \& Megson 2007). In vitro, cultured human endothelial cells increase NO synthesis in response to physiological concentrations of testosterone via nongenomic activation of intracellular signalling pathways and $\mathrm{Ca}^{2+}$ influx (Goglia et al. 2010, Yu et al. 2010, Campelo et al. 2012). Moreover, increased endothelial NOS (eNOS) expression and phosphorylation were observed in testosterone- and DHT-treated human umbilical vein endothelial cells (HUVECs) stimulated with hydrogen peroxide to induce senescence (Ota et al. 2012). In addition, testosterone significantly increased NO production via comparable mechanisms in rat aortic strips (Campelo et al. 2012), and testosterone stimulates NO synthesis, which consequently increases cyclic guanosine monophosphate (cGMP) formation to induce vasorelaxation in VSMCs (Deenadayalu et al. 2001, White et al. 2007).

A large amount of research has focussed on the vasoreactive mechanisms of testosterone in the penile tissue with regard to sexual function and ED. In patients with $\mathrm{ED}$, there is a positive correlation between free testosterone levels and the compliance of cavernous arteries of the penis, suggesting an involvement of circulating androgens in the regulation of intrapenile vasodilatation (Aversa et al. 2000). Similar to alternative vascular beds, one of the major actions of testosterone is on NO and its signalling pathways. The expression of NOS inside the penis is partially dependent on the presence of adequate androgen levels (Penson et al. 1996, Mills \& Lewis 1999, Mills et al. 1999a, Aversa et al. 2000). Androgen deprivation leads to a reduction in neuronal NOS expression associated with a decrease of intracavernosal pressure in penile arteries during erection, an effect that is promptly reversed by androgen replacement therapy (Lugg et al. 1995, Penson et al. 1996, Mills et al. 1999b). In addition to direct effects on NOS expression, testosterone may also affect phosphodiesterase type 5 (PDE5 (PDE5A)) gene expression, an enzyme controlling the degradation of
cGMP, which acts as a vasodilatory second messenger (Morelli et al. 2004). PDE5 inhibitors are currently the firstline treatment option for ED (Lee 2011); however, the efficacy of their use may be at least in part dependent upon the androgen status. Indeed, the response to PDE5 inhibitors for ED therapy was blunted in patients with subclinical hypogonadism (Guay et al. 2001, Kalinchenko et al. 2003) and PDE5 inhibitors are ineffective in improving erectile function in androgen-deficient animals (Traish et al. 1999). However, combined therapy with testosterone replacement and sildenafil in hypogonadal men converts $60 \%$ of sildenafil non-responders to responders (Greenstein et al. 2005, Shabsigh et al. 2004).

Vessel structure Testosterone is also thought to modulate VSMCs through the upregulation of proliferation genes and through possible inhibitory interactions with intracellular signalling pathways induced by pro-inflammatory cytokines, decreasing inflammationinduced apoptosis and promoting proliferation (Williams et al. 2002, Nakamura et al. 2006). Although some studies have linked abnormal VSMC proliferation to the pathogenesis of both atherosclerosis and re-stenosis (for review, refer to Rivard \& Andrés (2000)), smooth muscle cells secrete and deposit extracellular matrix proteins (collagen, elastin, etc.) often considered protective against atherosclerotic plaque destabilisation (Johnson 2007). However, smooth muscle cells also release numerous proteases (matrix metalloproteinases (MMPs)) that are capable of digesting matrix proteins, making the role of VSMC proliferation in atherosclerotic plaque progression a complex issue that is not fully understood. Likewise, VSMC apoptosis can induce features of plaque vulnerability in atherosclerosis, yet the accumulation of VSMCs is also viewed as responsible for lesion formation (Clarke et al. 2006). Thus, the significance of the action of testosterone on VSMC apoptosis and proliferation in atherosclerosis is difficult to delineate and may be dependent upon the stage of plaque development.

Whether as a result of smooth muscle cell proliferation or due to the build-up of lipid and inflammation in atherosclerosis, thickening of the intima-media leads to detrimental alterations in local haemodynamics, shear stress, blood pressure and ultimately vascular function. Intima-media thickness (IMT, a measure of the thickness of the innermost two layers of the arterial wall) is associated with atherosclerosis and is viewed as a surrogate endpoint for evaluating the regression and/or progression of atherosclerotic CVD. Several human studies have shown that carotid IMT (CIMT) and aortic calcification negatively

Published by Bioscientifica Ltd. 
correlate with serum testosterone (Hak et al. 2002, van den Beld et al. 2003, Fukui et al. 2003, Muller et al. 2004, Demirbag et al. 2005, Mäkinen et al. 2005, Svartberg et al. 2006). Low levels of testosterone in men were inversely related to the mean progression of IMT in the common carotid artery even after adjusting for age, and this relationship was found to be independent of other cardiovascular risk factors (Muller et al. 2004). We, and others, have discovered that long-term testosterone treatment reduced CIMT in men with low testosterone levels and angina (Rosano et al. 1999, Mathur et al. 2009, Zitzmann et al. 2009).

Men with CVD in the majority of epidemiological studies have been demonstrated to have a high prevalence of low testosterone levels (Jones \& Saad (2009) and Jones $(2010 a, b)$, for review). There is also an inverse relationship between the degree of coronary atherosclerosis and testosterone (Phillips et al. 1993, Nettleship et al. 2007b). A case-control study of men undergoing coronary angiography found that those with evidence of coronary atheroma had lower levels of bioavailable testosterone compared with men with normal coronary arteries (English et al. 2000c). The key question is whether or not the low testosterone state contributes to the pathogenesis of atherosclerosis or whether or not it is merely a biomarker of ill-health.

\section{Potential signalling mechanisms of testosterone in vascular reactivity}

The mechanisms by which testosterone acts on the vasculature to elicit effects on tone, compliance and function are a matter of some debate. The rapid onset of acute vasodilatory actions of testosterone (within minutes) and evidence from ion channel investigations suggest that at least some of these actions are nongenomic, function independently of (AR) nuclear translocation and do not require protein synthesis (Jones et al. 2003b). Indeed, as has been discussed previously, the direct actions of testosterone on ion channel function bypass the necessity for classical nuclear AR activity. This is supported by the fact that vasodilatory effects have been shown with testosterone bound to BSA, which prevents transmembrane diffusion and/or endocytosis and, therefore, access to the cytoplasmic AR in smooth muscle cells (Ding \& Stallone 2001). Furthermore, polar testosterone analogues that are unable to permeate the cell membrane have been reported to produce a greater vasodilatory response than non-polar, permeable analogues (Ding \& Stallone 2001), and similarly non-genomic testosterone analogues elicit increased vasodilatation compared with the genome-acting analogues (Yue et al. 1995, Ding \& Stallone 2001). These data may allow for the presence of cell surface ARs, and binding sites in cell membranes that display features compatible with rapid steroid signalling have been characterised (Gerdes et al. 2000). However, the acute vasodilatory actions of testosterone in rat coronary arteries and thoracic aorta of mice were not abolished by the AR blocker flutamide, suggesting an AR-independent mechanism (Channer \& Jones 2003, Jones et al. 2004a). Likewise, additional receptor antagonist studies have further indicated that neither intracellular nor membrane-associated ARs are required for the rapid vasodilator effect (Yue et al. 1995, Tep-areenan et al. 2002). Research carried out in our laboratory has demonstrated that testosterone-mediated vasodilatation is maintained in vessels isolated from testicular feminised (Tfm) mice, which lack a functional AR, supporting AR-independent mechanisms and potentially direct actions on ion channel function in acute responses (Jones et al. 2003a).

While acute responses appear to be AR independent, long-term AR-mediated effects on the vasculature have also been described, primarily in the context of vascular tone regulation via the modulation of gene transcription. Indeed, the AR is expressed ubiquitously in the cells of the vasculature. Testosterone and DHT increased the expression of eNOS in HUVECs, an effect that was significantly reduced by AR blockade (Goglia et al. 2010). Furthermore, $A r$ knockout (ARKO) mice displayed significantly reduced aortic eNOS expression and phosphorylation compared with the wild-type mice, indicating that AR activation may be required for the preservation of $\mathrm{NO}$ bioavailability and the regulation of vascular tone (Ikeda et al. 2009). In addition to slower acting gene regulation, rapid AR activation of intracellular signalling pathways has also been suggested. Yu et al. (2010) described how the rapid phosphorylation of eNOS or NO production was abolished by pre-treatment with an AR antagonist, nilutamide, or by transfection with $A R$ siRNA and that DHT also stimulated eNOS phosphorylation in human aortic endothelial cells (HAECs). The authors suggest that the activation of PI3-kinase/Akt intracellular signalling pathway and the direct interaction of the AR with $\mathrm{p} 85 \alpha$ (the regulatory subunit of PI3-kinase) were responsible for the observed effects (Yu et al. 2010). Furthermore, the lack of a functional AR in Tfm mice is associated with reduced endothelium-dependent vasodilatation even when the low endogenous levels of testosterone (characteristic of Tfm mice) are restored to the wild-type levels, indicating

Published by Bioscientifica Ltd. 
that AR genomic pathways also influence vascular tone (Jones et al. 2003a).

The influence of ERs on the vascular action of testosterone, via conversion to $\mathrm{E}_{2}$ by aromatase, has also been proposed as a potential mechanism for the observed AR-independent effects. Indeed, $\mathrm{E}_{2}$ is recognised to elicit marked vasodilatation in a variety of vascular beds (Chester et al. 1995, Browne et al. 1999, Teoh et al. 2000a,b, English et al. 2001, Salom et al. 2001), and aromatase is expressed in the cells of the vasculature (Harada et al. 1999, Mukherjee et al. 2002). Additionally, oestrogens have been shown to activate eNOS and stimulate NO production in an ER $\alpha$-dependent manner (Chen et al. 1999, Simoncini et al. 2000a). Several studies, however, have demonstrated that the vasodilatory actions of testosterone are not reduced by aromatase inhibition (Yue et al. 1995, Tep-areenan et al. 2002) or ER antagonism (Chou et al. 1996) and non-aromatisable DHT elicited similar vasodilation to testosterone treatment in arterial smooth muscle (Deenadayalu et al. 2001, Hall et al. 2006). Furthermore, the vasodilatory effects triggered by $\mathrm{E}_{2}$ were reported to be significantly lower than those observed with testosterone treatment in the pulmonary vasculature (English et al. 2001), leading to the assumption that aromatase-mediated conversion of testosterone into $\mathrm{E}_{2}$ and subsequent activation of the ER are unlikely to be involved in the response in this vascular bed.

\section{Testosterone and vascular inflammation}

It is now accepted that atherosclerosis is a chronic inflammatory pathology. Individuals with hyperlipidaemia and signs of systemic inflammation develop atherosclerosis, with specific defects in lipid processing and immune activity consequentially occurring at the vessel wall. The initiating factors leading to specific local vascular changes may be numerous and often remain elusive in cardiovascular research; however, it is known that the activation of endothelial cells promotes the adhesion of leukocytes to the blood vessel wall as an early atherogenic event. This activation also leads to increased vascular permeability for not only inflammatory leukocytes, but also the circulating lipid components, such as LDL. LDL in the intima is oxidised to form pro-inflammatory cell-activating oxLDLs, which further promote the early stages of atherogenesis. The build-up of lipid and inflammation in the vessel wall causes changes in local fluid dynamics with the thickening of the intima consequentially leading to the loss of normal vascular reactivity with the associated detrimental outcomes discussed previously.
The anti-inflammatory mechanisms of androgens have been long recognised, yet evidence from previous studies that have investigated sex hormones and inflammatory markers has not been consistent (Jones \& Saad 2009). Observational evidence suggests that several pro-inflammatory cytokines (including interleukin $1 \beta$ (IL1 $\beta)$, IL6, tumour necrosis factor $\alpha$ (TNF $\alpha$ ), and highly sensitive CRP) and serum testosterone levels are inversely associated in patients with CAD, T2DM and/or hypogonadism (Yang et al. 2005, Maggio et al. 2006, Kapoor et al. 2007, Nettleship et al. 2007b). Moreover, Nettleship et al. (2007b) demonstrated an association between circulating levels of IL1 $\beta$ and atherosclerotic burden and found that patients with the highest IL1 $\beta$ concentrations had lower endogenous testosterone levels. Additionally, TRT has been reported to significantly reduce TNF $\alpha$ and elevate the circulating anti-inflammatory IL10 in hypogonadal men with CVD (Malkin et al. 2004a,b). The Moscow Study demonstrated that 30 weeks of testosterone treatment to normalise levels in hypogonadal men with the MetS resulted in a significant reduction in the circulating CRP, IL1 $\beta$ and TNF $\alpha$, with a trend towards lower IL6 compared with placebo (Kalinchenko et al. 2010). Following 1 year of treatment with parenteral testosterone undecanoate, CRP decreased significantly in hypogonadal elderly men (Haider et al. 2009). Khosla et al. (2002) reported that TNF $\alpha$, IL6 and IL6 soluble receptor were elevated in elderly men where hypogonadism was induced by GNRH antagonists. Testosterone replacement in these men abolished this heightened inflammatory response. Conversely, a similar study demonstrated that testosterone therapy had no effect on serum TNF $\alpha$ concentrations in men with chronic heart failure (Pugh et al. 2005) and testosterone replacement in hypogonadal men with T2DM had no effect on the TNF $\alpha$, IL6 or CRP levels (Kapoor et al. 2007). Likewise, in a prospective study of older men, the administration of DHT or human chorionic gonadotrophin (to stimulate testosterone synthesis from the Leydig cells) did not significantly alter the highsensitivity CRP, soluble vascular cell adhesion molecule 1 (sVCAM-1) or soluble intracellular adhesion molecule (sICAM) levels (Ng et al. 2002).

TRT has been shown in some studies to lower serum levels of the adipocytokine, adiponectin, particularly in hypogonadal men with T2DM (Lanfranco et al. 2004, Page et al. 2005, Kapoor et al. 2007). Higher levels of serum adiponectin have been shown to lower cardiovascular risk. The interventional studies were short-term and may reflect the reduction in total fat mass as also observed

Published by Bioscientifica Ltd. 
with a reduction in leptin. The long-term effect of testosterone on adiponectin is not known.

In addition to influencing the systemic markers of inflammation, testosterone has been shown to inhibit TNF $\alpha$, IL1 $\beta$ and IL6 released from cultured peripheral blood monocytes isolated from androgen-deficient men with T2DM (Corrales et al. 2006; Fig. 5). The physiological and supraphysiological concentrations of testosterone reduced the expression and secretion of TNF $\alpha$ and IL1 $\beta$ in monocyte-derived macrophages obtained from a CHD age-relevant population, although no effects were observed on IL6 and CRP expression (Corcoran et al. 2010). In another study, IL6 production was shown to be reduced in isolated human monocytes from a small healthy male population following in vitro testosterone treatment (Kanda et al. 1996).

Animal studies support the reported beneficial effects of androgen supplementation on atherosclerosis in males, with evidence for AR-dependent and -independent actions, resulting in the underlying mechanisms being difficult to elucidate (Bruck et al. 1997, Alexandersen et al. 1999, Nathan et al. 2001, Nettleship et al. 2007a). The administration of physiological levels of testosterone significantly reduced high-cholesterol diet-induced fatty streak formation in the aortic root of Tfm mice, whereby

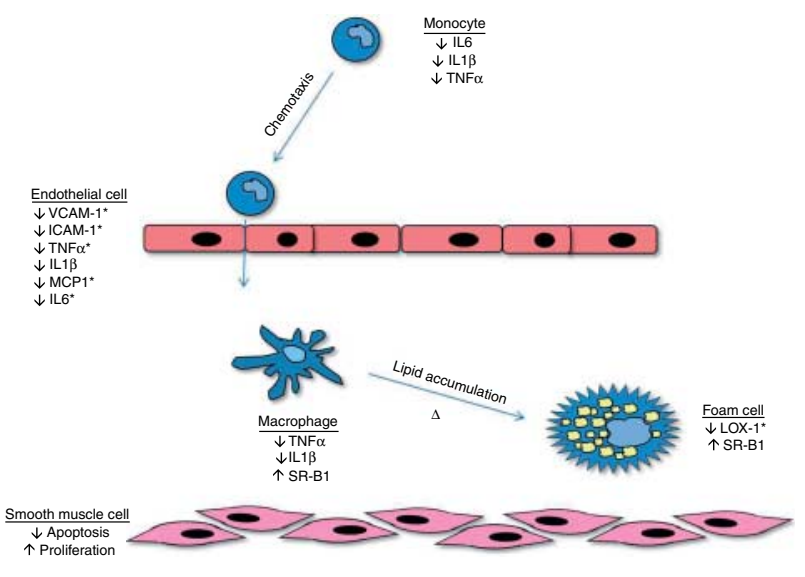

Figure 5

Potential cell-specific anti-inflammatory effects of testosterone. Androgens are known anti-inflammatory agents, but the specific actions of testosterone on vascular and immune cells have not been inconsistent. Testosterone has been shown, however, to reduce pro-inflammatory cytokine production and adhesion molecule expression in a number of athero-relevant cell types including monocytes, macrophages, endothelial cells, smooth muscle cells and foam cells. Testosterone may also inhibit the formation of foam cells (open triangle). IL, interleukin; TNF, tumour necrosis factor; MCP, monocyte chemoattractant protein; ICAM, intracellular adhesion molecule; VCAM, vascular cell adhesion molecule; LOX-1, lectin-like oxidised LDL receptor-1; SR-B1, scavenger receptor-B1. *Effects also observed with DHT. the prominent lesional cells were demonstrated to be macrophages (Nettleship et al. 2007a, Kelly et al. 2012). In addition, a recent study using ARKO mice on an apolipoprotein E-deficient background (which are testosterone deficient) has shown that replacing testosterone to physiological levels reduced atherosclerotic lesion area and complexity compared with placebo, but not to the same extent as that observed in testosterone-treated orchidectomised wild-type controls (Bourghardt et al. 2010). Although consistent with AR-dependent and -independent mechanisms, the individual contribution of these pathways to the effect of testosterone on atherogenesis currently remains unknown.

The anti-inflammatory effects of testosterone may therefore act on the vasculature by influencing both systemic inflammation and leukocyte activation to reduce localised atheroma development in the susceptible regions of blood vessels. A direct anti-inflammatory effect of testosterone on the cells of the vasculature has also been proposed, although the evidence is limited and often contradictory.

\section{Influence of testosterone on vascular cell inflammation}

Research suggests that the expression of VCAM-1, as induced by pro-inflammatory cytokines such as TNF $\alpha$ or interferon $\gamma$ (IFN $\gamma$ (IFNG)) in endothelial cells, can be attenuated by treatment with testosterone (Hatakeyama et al. 2002, Mukherjee et al. 2002). Testosterone also inhibits the production of pro-inflammatory cytokines such as IL6, IL1 $\beta$ and TNF $\alpha$ in a range of cell types including human endothelial cells (Hatakeyama et al. 2002).

TNF $\alpha$-induced VCAM-1 expression in HAECs was inhibited by testosterone treatment, suggesting that androgens play an important role in the prevention of atherogenesis (Hatakeyama et al. 2002). This study additionally described the inhibition of nuclear factor $\kappa B$ $(\mathrm{NF} \kappa \mathrm{B})$ activation, not only as a potential mechanism for decreased VCAM-1 expression, but also as a prospective modulator of several other inflammatory gene targets known to be activated by this transcription factor. The promoter regions of the genes encoding ICAM-1, VCAM-1 and E-selectin all contain at least one $\kappa \mathrm{B}$ site required for cytokine gene activation (Neish et al. 1992, Kaszubska et al. 1993, Hou et al. 1994, Read et al. 1994). Norata et al. (2006) furthered this notion by elegantly demonstrating a decreased inflammatory response to TNF $\alpha$ and lipopolysaccharide (LPS) in human endothelial cells when treated with DHT. This included a reduction in VCAM-1 and ICAM-1 expression as well as a decreased IL6, monocyte

Published by Bioscientifica Ltd. 
chemoattractant protein 1 (MCP1 (CCL2)) and TNF $\alpha$ release. The authors have recently extended these findings by demonstrating that DHT can reduce TNF $\alpha$-induced MCP1 expression in endothelial cells (Norata et al. 2010). Although these studies were performed in HUVECs, and therefore may not be reflective of the behaviour of other endothelial cell types, the inhibition of VCAM-1 expression supports the findings of previous investigations (Hatakeyama et al. 2002). Zhang et al. (2002), however, found no effect of testosterone on TNF $\alpha$ receptor expression in $\mathrm{TNF} \alpha$-stimulated endothelial cells and, contradictory to the proposed atheroprotective role of testosterone, demonstrated androgen enhancement of TNF $\alpha$-induced E-selectin and VCAM-1 upregulation. Several studies have also demonstrated that the cytokine-stimulated upregulation of adhesion molecules is increased in cultured endothelial cells upon treatment with androgens (McCrohon et al. 1999, Mukherjee et al. 2002, Death et al. 2004).

\section{Potential signalling mechanisms of testosterone in vascular inflammation}

The conflicting experimental observations regarding testosterone may in part be due to differences in the cell type studied, the need for often supraphysiological treatment concentrations in vitro and differences in the inflammatory stimuli or target investigated. The key to unravelling the link between testosterone and its role in atherosclerosis may lay in the understanding of testosterone signalling and the cross-talk between receptors and intracellular events that result in pro- and/or antiinflammatory actions in athero-sensitive cells.

AR mechanisms Through direct AR antagonism, Zhang et al. (2002) completely abrogated the androgen enhancement of TNF $\alpha$-induced E-selectin and VCAM-1 upregulation, indicating that testosterone functions through the AR to modulate adhesion molecule expression. In support of this, McCrohon et al. (1999) reported that DHT increased the expression of VCAM-1 in HUVECs without cytokine influence and that this effect was antagonised by the blockade of the AR. A recent study using cultured human stromal cells derived from benign prostatic hyperplasia patient biopsy samples demonstrated that a pre-treatment with DHT reduced the cytokine-stimulated inflammatory response (Vignozzi et al. 2012). Indeed, DHT inhibited NFאB activation and thereby suppressed the secretion of several inflammatory/growth factors, with the most pronounced effects on IL8, IL6 and basic fibroblast growth factor. Norata et al. (2006) also demonstrated that DHT could inhibit an LPS-induced upregulation of MCP1 in HUVECs, an effect that was abolished by AR antagonism. The authors additionally reported that the upregulation of MCP1 expression by TNF $\alpha$ stimulation was partially, but significantly, inhibited by DHT treatment, interestingly an effect that was not altered by AR blockade. Both $\mathrm{NF \kappa B}$ and $\mathrm{AR}$ act at the transcriptional level and have been experimentally found to be antagonistic to each other, limiting gene expression to the relative nuclear presence of either factor (McKay \& Cidlowski 1998). As the AR and NFKB are mutual antagonists, their interaction and influence on functions can be bidirectional, with inflammatory agents that activate $\mathrm{NF \kappa B}$ interfering with normal androgen signalling as well as the AR interrupting $\mathrm{NF \kappa B}$ inflammatory transcription. If this is the case, prolonged exposure of vascular cells to the inflammatory activation of NFKB associated with atherosclerosis may reduce or alter any potentially protective effects of testosterone. In addition, physical interactions of $\mathrm{NF \kappa B}$ subunits and promoter regions of $A R$ gene have been observed (Supakar et al. 1995), suggesting a possible feedback loop, whereby inflammatory activities in cells promote increased androgen sensitivity through increased receptor synthesis. The in vivo significance of these interactions, however, remains to be established. In addition to the interaction of testosterone with $\mathrm{NF \kappa B}$, preliminary data propose that DHT and $\mathrm{IFN}_{\gamma}$ also modulate each other's signalling through interaction at the transcriptional level, suggesting that androgens down-regulate IFN-induced genes (Bettoun et al. 2005).

In contrast, Death et al. (2004) support a role of the AR in the enhancement of pro-inflammatory cytokinestimulated expression of adhesion molecules. The treatment of HUVECs with DHT and IL1 $\beta$ significantly increased VCAM-1 expression, and this was blocked by AR antagonism with hydroxyflutamide. The authors further demonstrated that DHT increased VCAM-1 promoter activity via NFKB activation, although not via direct interactions between the AR and NFאB. Instead, DHT was demonstrated to decrease the level of inhibitory $\kappa \mathrm{B}(\mathrm{I} \kappa \mathrm{B})$ protein through heightened degradation, thus activating NFאB and subsequent VCAM-1 expression.

ER mechanisms Mukherjee et al. (2002) showed that testosterone could attenuate TNF $\alpha$-induced VCAM-1 upregulation in HUVECs, an action that was abolished by both ER antagonism and aromatase inhibition.

Published by Bioscientifica Ltd. 
This study utilised HUVECs of female origin and may not be directly comparable to investigations with male endothelial cells. In parallel, $\mathrm{E}_{2}$ can inhibit IL1-induced ICAM-1, VCAM-1 and E-selectin expression in HUVECs isolated from a female foetus (Caulin-Glaser et al. 1996). Xing et al. (2007) reported that $\mathrm{E}_{2}$ inhibits the mRNA expression of Icam1, Vcam1, P-selectin and MCP1 in rat aortic SMCs and further described that this effect was attenuated by ER $\beta$ blockade. Additionally, Nakagami et al. (2010) have recently demonstrated that $\mathrm{E}_{2}$ inhibits lipoprotein-a (an atherogenic lipoprotein)-induced expression of VCAM-1, ICAM-1 and E-selectin in bovine aortic endothelial cells and that IL1 $\beta$, TNF $\alpha$ and MCP1 in macrophages differentiated from the THP- 1 monocyte cell line. Indeed, $\mathrm{E}_{2}$ inhibits MCP1 expression in rat thoracic aorta VSMCs (Jiang et al. 2010) and inhibits human monocyte migration towards MCP1 in the culture, an effect that was abolished by ER blockade (Yamada et al. 1996). The inhibition of monocyte migration was not demonstrated with testosterone treatment, suggesting that the ER effects are independent of testosterone conversion (Yamada et al. 1996). Aromatase expression, however, was not assessed in these cells.

Simoncini et al. (2000b) also showed that $\mathrm{E}_{2}$ inhibited the expression of VCAM-1 when induced by LPS, IL1 $\alpha$ or TNF $\alpha$. The authors considered this effect to be via decreased NFKB activity. Indeed, the ER has been shown to inhibit NFкB activity in several cell lines (Kalaitzidis \& Gilmore 2005). The ER can directly bind the subunits of $\mathrm{NF \kappa} B$ in vitro and inhibit transcriptional activity possibly by preventing DNA binding or by inhibiting essential coactivator protein association preventing their interaction with NFאB (Stein \& Yang 1995). However, ER-NFאB complexes have not been reported. The ER has been suggested to influence $\mathrm{NF} \kappa \mathrm{B}$ activities indirectly through the inhibition of I $\mathrm{B}$ kinase (IKK) complex that regulates I $\kappa$ B degradation (Simoncini et al. 2000a,b). Norata et al. (2010) suggest that part of the testosteronemediated atheroprotective effects could depend on ER activation mediated by the testosterone/DHT $3 \beta$-derivative, $3 \beta$-Adiol. Indeed, TNF $\alpha$-induced induction of ICAM-1, VCAM-1 and E-selectin as well as MCP1 and IL6 was significantly reduced by a pre-incubation with $3 \beta$-Adiol in HUVECs (Norata et al. 2010). These effects were inhibited by selective ER $\beta$ antagonism. In the same study, $3 \beta$-Adiol also reduced LPS-induced gene expression of IL6, TNF $\alpha$, cyclooxygenase 2 (COX2 (PTGS2)), CD40, $\mathrm{CX}_{3} \mathrm{CR} 1$, plasminogen activator inhibitor-1, MMP9, resistin, pentraxin-3 and MCP1 in the monocytic cell line U937 (Norata et al. 2010). This study suggests that testosterone metabolites, other than those generated through aromatisation, could exert anti-inflammatory effects that are mediated by ER activation.

In contrast, Aziz \& Wakefield (1996) demonstrated that $\mathrm{E}_{2}$ enhanced the expression of E-selectin after TNF $\alpha$ stimulation of endothelial cells and supported similar findings from a previous study where VCAM-1 and ICAM-1 were additionally upregulated, promoting leukocyte adherence (Cid et al. 1994). Both these investigations reported a lack of oestrogen modulation on adhesion molecule expression following IL1 $\beta$ stimulation, whereas Zhang et al. (2002) reported that $\mathrm{E}_{2}$ enhanced TNF $\alpha$-induced mRNA and surface endothelial cell expression of E-selectin and VCAM-1. The effect was completely abrogated by pre-incubating the cells with the oestrogen antagonist tamoxifen.

AR-and ER-independent mechanisms In Tfm mice (non-functional AR and low endogenous testosterone), serum TNF $\alpha$ and IL6 were significantly elevated compared with those in littermates receiving a normal diet, and testosterone treatment significantly reduced serum IL6 in Tfm mice receiving a high-cholesterol diet (Kelly et al. 2012). Conversely, Bourghardt et al. (2010) observed no effect of testosterone treatment on IL6 or other cytokines in ARKO mice. Fatty streak formation as an early indication of atherosclerosis was also shown to be increased in Tfm mice (Kelly et al. 2012). Testosterone treatment significantly reduced aortic lipid deposition and consequently inflammatory monocytes/macrophages present in these early lesions in Tfm mice compared with placebo. No differences were observed between animal groups for the expression of the atherogenic chemokine fractalkine $\left(\mathrm{CX}_{3} \mathrm{CL} 1\right)$ and its receptor $\left(\mathrm{CX}_{3} \mathrm{CR} 1\right)$ in the plaque area. Despite this lack of local anti-inflammatory effects of testosterone on specific atherogenic markers, this study supports a role for AR-independent effects in atheroprotection; however, the influence of the ER was not investigated. A similar study in Tfm mice demonstrated that the beneficial effects of testosterone treatment on fatty streak formation were only partially reduced by ER $\alpha$ blockade with fulvestrant and aromatase inhibition with anastrozole, suggesting that testosterone may also act via undetermined ARand ER-independent mechanisms in atheroprotection (Nettleship et al. 2007a).

Using the non-aromatisable androgen DHT, Osterlund et al. (2010) demonstrated that human coronary artery smooth muscle cells (HCASMCs) attenuate their increased expression of the inflammatory

Published by Bioscientifica Ltd. 
mediator COX2 under inflammatory conditions (LPS or IL1 $\beta$ ) when co-treated with DHT. This effect of DHT was not altered by AR antagonism with bicalutamide. Interestingly, under normal conditions without proinflammatory stimulation, DHT alone increased COX2 levels compared with the vehicle and AR antagonism attenuated the response. The authors suggest that DHT differentially effects COX2 levels under physiological and pathophysiological conditions in human coronary artery smooth muscle cells and via AR-dependent and independent mechanisms influenced by the physiological state of the cell (Osterlund et al. 2010). DHT was also shown to suppress hypoxia-induced upregulation of COX2 by inhibiting hypoxia-inducible factor $1 \alpha$ (HIF $1 \alpha$ (HIF1A)) DNA binding and subsequent transcription of the COX2 gene in primary human brain VSMCs (Zuloaga \& Gonzales 2011). Similarly, these effects were not reversed by AR blockade.

Consistent with a membrane mode of action, testosterone and DHT can activate second-messenger cascades through the SHBG receptor complex. Such an activation of the SHBG receptor transduces its signal via a G-protein, leading to the activation and rapid generation of cAMP (Rosner et al. 1999). In the case of testosterone ion channel modulation and subsequent second-messenger activation, relatively little is known about the ultimate cellular effect, but physiological genotropic effects that impact on cell function are likely, and in cells relevant to the atherosclerotic process, these functions may be linked to inflammation. $\mathrm{Ca}^{2+}$ functions as a ubiquitous second-messenger molecule and may be involved in a mechanism by which testosterone influences intracellular signal cascades. The activation of these cascades can modulate the activity of transcription factors and subsequent gene expression. Whether these genes have an inflammatory function remains unclear.

\section{Testosterone and cardiovascular safety}

TRT to treat male hypogonadism has been available since 1939. Concerns have been raised in regard to the safety of TRT in men with CVD. There are, however, a number of systematic meta-analyses of clinical trials of TRT that have not demonstrated an increased risk of adverse cardiovascular events or mortality (Haddad et al. 2007, Fernández-Balsells et al. 2010, Corona et al. 2011, Carson $\&$ Rosano 2011). The TOM trial, which was designed to investigate the effect of TRT on frailty in elderly men, was terminated prematurely as a result of an increased incidence of cardiovascular-related events after 6 months in the treatment arm (Basaria et al. 2010). An elderly cohort of frail men with a high proportion having multiple comorbidities were given $100 \mathrm{mg} /$ day testosterone gel, twice the recommended initiation dose of testosterone gel $(50 \mathrm{mg} /$ day), with six men having their dose increased to $150 \mathrm{mg} /$ day. The cardiovascular-related events were heterogeneous and included self-reported syncope and oedema, the latter a known side effect of the supraphysiological levels of testosterone. The study was not powered to detect a statistically significant increase in cardiovascular events. A similar trial that also investigated the effect of testosterone therapy on frailty using a conventional testosterone dosage $(50 \mathrm{mg} /$ day $)$ did not report any difference in cardiovascular events between the treatment and placebo arms (Srinivas-Shankar et al. 2010). Furthermore, trials of TRT in men with either chronic stable angina or chronic cardiac failure have also found no increase in either cardiovascular events or mortality in studies up to 12 months (English et al. 2000b, Malkin et al. 2006b, Caminiti et al. 2009). In addition, a median 5-year follow-up study of elderly communitydwelling men ( $n=2416$; $61-81$ years old) found that men in the highest quartile of serum testosterone had a reduced number of cardiovascular events (HR 0.7) compared with men in the lower three quartiles (Ohlsson et al. 2011). Evidence may therefore suggest that low testosterone levels and testosterone levels above the normal range have an adverse effect on CVD, whereas testosterone levels titrated to within the mid- to upper-normal range have at least a neutral effect or, taking into account the knowledge of the beneficial effects of testosterone on a series of cardiovascular risk factors, there may possibly be a cardioprotective action. A large long-term ideally 5-year outcome study would be required to provide the evidence.

\section{Summary}

The effect of testosterone on human vascular function is a complex issue and may be dependent upon the underlying androgen and/or disease status. Although not definitive, the majority of studies suggest that testosterone may display both acute and chronic vasodilatory effects upon various vascular beds at both physiological and supraphysiological concentrations and via endothelium-dependent and -independent mechanisms (Manolakou et al. 2009). In addition, testosterone may also chronically condition vessel response to other vasoactive agents to influence reactivity, with treatment in testosterone-deficient men potentially restoring vascular function.

Published by Bioscientifica Ltd 
Concurrently, testosterone has demonstrated anti-inflammatory effects clinically and TRT can improve atherosclerosis assessed non-invasively in hypogonadal men and in animal studies. Although conflicting and contradictory experimental evidence exists, testosterone can influence cell-specific vascular inflammation (Fig. 5) and may potentially be a mechanism by which TRT protects against atherogenesis in animal models. Testosterone may, therefore, alleviate the haemodynamic symptoms of atherosclerosis and improve atherosclerotic outcomes associated with disturbed flow patterns and dysfunctional vascular reactivity and offer potential therapeutic benefits for CVD. The mechanism of the action of testosterone on vascular cells remains unknown but may include classical steroid receptor activation and modulation of gene transcription (genomic), AR-mediated activation of rapid intracellular signalling pathways (non-genomic), direct ion channel modulation and/or activation of a thus far unknown membrane receptor to elicit these effects on vascular function and vascular inflammation.

It is important to recognise that findings from preclinical studies do not always translate into normal human biology and the clinical setting and therefore necessitate a cautious interpretation. Some of the in vitro studies discussed in this review provide contradictory results, which may occur because of differing experimental conditions. However, the current scientific literature supports firstly the notion that testosterone is a vascular hormone that does affect vasoreactivity and secondly that testosterone can beneficially enhance biological processes involved in atheroprotection, in particular, lipid deposition and inflammation both within the arterial wall and in the circulation. Clinical studies have shown benefits for up to one year for cardiac ischaemia and its symptom of angina, cardiac failure and certain cardiovascular risk factors. While testosterone has therapeutic potential as a vascular hormone, further large randomised placebocontrolled trials are required to elucidate its long-term clinical relevance to cardiovascular health in men. Whether or not testosterone directly protects against atherosclerosis and reduces cardiovascular events including mortality therefore warrants further investigation, and the complex underlying vascular mechanisms of action require clarification.

\section{Declaration of interest}

T H J has acted as a consultant for ProStrakan (Galashiels, UK) and Bayer Healthcare and has received research grants from Bayer Healthcare and honoraria for educational lectures and advisory boards for Bayer Healthcare, Lilly, Merck and ProStrakan.

\section{Funding}

This research did not receive any specific grant from any funding agency in the public, commercial or not-for-profit sector.

\section{References}

Alexandersen P, Haarbo J, Byrjalsen I, Lawaetz H \& Christiansen C 1999 Natural androgens inhibit male atherosclerosis: a study in castrated, cholesterol-fed rabbits. Circulation Research 84 813-819. (doi:10.1161/ 01.RES.84.7.813)

Alvarez E, Cairrão E, Morgado M, Morais C \& Verde I 2010 Testosterone and cholesterol vasodilation of rat aorta involves L-type calcium channel inhibition. Advances in Pharmacological Sciences. (doi:10.1155/2010/ 534184)

Anderson TJ, Uehata A, Gerhard MD, Meredith IT, Knab S, Delagrange D, Lieberman EH, Ganz P, Creager MA, Yeung AC et al. 1995 Close relation of endothelial function in the human coronary and peripheral circulations. Journal of the American College of Cardiology 26 1235-1241. (doi:10.1016/0735-1097(95)00327-4)

Araujo AB, Dixon JM, Suarez EA, Murad MH, Guey LT \& Wittert GA 2011 Clinical review: endogenous testosterone and mortality in men: a systematic review and meta-analysis. Journal of Clinical Endocrinology and Metabolism 96 3007-3019. (doi:10.1210/jc.2011-1137)

Aversa A, Isidori AM, De Martino MU, Caprio M, Fabbrini E, Rocchietti-March M, Frajese G \& Fabbri A 2000 Androgens and penile erection: evidence for a direct relationship between free testosterone and cavernous vasodilation in men with erectile dysfunction. Clinical Endocrinology 53 517-522. (doi:10.1046/j.1365-2265.2000.01118.x)

Aziz KE \& Wakefield D 1996 Modulation of endothelial cell expression of ICAM-1, E-selectin, and VCAM- 1 by $\beta$-estradiol, progesterone, and dexamethasone. Cellular Immunology 167 79-85. (doi:10.1006/ cimm.1996.0010)

Barrett-Connor E \& Khaw KT 1988 Endogenous sex hormones and cardiovascular disease in men. A prospective population-based study. Circulation 78 539-545. (doi:10.1161/01.CIR.78.3.539)

Bartlett DB, Firth CM, Phillips AC, Moss P, Baylis D, Syddall H, Sayer AA, Cooper C \& Lord JM 2012 The age-related increase in low-grade systemic inflammation (inflammaging) is not driven by cytomegalovirus infection. Aging Cell 11 912-915. (doi:10.1111/j.1474-9726. 2012.00849.x)

Basaria S, Coviello AD, Travison TG, Storer TW, Farwell WR, Jette AM, Eder R, Tennstedt S, Ulloor J, Zhang AQ et al. 2010 Adverse events associated with testosterone administration. New England Journal of Medicine 363 109-122. (doi:10.1056/NEJMoa1000485)

van den Beld AW, Bots ML, Janssen JA, Pols HA, Lamberts SW \& Grobbee DE 2003 Endogenous hormones and carotid atherosclerosis in elderly men. American Journal of Epidemiology 157 25-31. (doi:10.1093/aje/kwf160)

Bettoun DJ, Scafonas A, Rutledge SJ, Hodor P, Chen O, Gambone C, Vogel R, McElwee-Witmer S, Bai C, Freedman L et al. 2005 Interaction between the androgen receptor and RNase L mediates a cross-talk between the interferon and androgen signaling pathways. Journal of Biological Chemistry 280 38898-38901. (doi:10.1074/jbc.C500324200)

Blacher J, Asmar R, Djane S, London GM \& Safar ME 1999 Aortic pulse wave velocity as a marker of cardiovascular risk in hypertensive patients. Hypertension 33 1111-1117. (doi:10.1161/01.HYP.33.5.1111)

Bourghardt J, Wilhelmson AS, Alexanderson C, De Gendt K, Verhoeven G, Krettek A, Ohlsson C \& Tivesten A 2010 Androgen receptor-dependent and independent atheroprotection by testosterone in male mice. Endocrinology 151 5428-5437. (doi:10.1210/en.2010-0663)

Browne M, Connolly C \& Docherty JR 1999 Vascular actions of $17 \beta$-oestradiol in rat aorta and mesenteric artery. Journal of Autonomic Pharmacology 19 291-299. (doi:10.1046/j.1365-2680.1999.00149.x)

Published by Bioscientifica Ltd. 
Bruck B, Brehme U, Gugel N, Hanke S, Finking G, Lutz C, Benda N, Schmahl FW, Haasis R \& Hanke H 1997 Gender-specific differences in the effects of testosterone and estrogen on the development of atherosclerosis in rabbits. Arteriosclerosis, Thrombosis, and Vascular Biology 17 2192-2199. (doi:10.1161/01.ATV.17.10.2192)

Cairrão E, Alvarez E, Santos-Silva AJ \& Verde I 2008 Potassium channels are involved in testosterone-induced vasorelaxation of human umbilical artery. Naunyn-Schmiedeberg's Archives of Pharmacology 376 375-383. (doi:10.1007/s00210-007-0213-3)

Caminiti G, Volterrani M, Iellamo F, Marazzi G, Massaro R, Miceli M, Mammi C, Piepoli M, Fini M \& Rosano GMC 2009 Effect of long-acting testosterone treatment on functional exercise capacity, skeletal muscle performance, insulin resistance, and baroreflex sensitivity in elderly patients with chronic heart failure a double-blind, placebo-controlled, randomized study. Journal of the American College of Cardiology 54 919-927. (doi:10.1016/j.jacc.2009.04.078)

Campelo AE, Cutini PH \& Massheimer VL 2012 Testosterone modulates platelet aggregation and endothelial cell growth through nitric oxide pathway. Journal of Endocrinology 213 77-87. (doi:10.1530/ JOE-11-0441)

Carson CC III \& Rosano G 2011 Exogenous testosterone, cardiovascular events, and cardiovascular risk factors in elderly men: a review of trial data. Journal of Sexual Medicine 9 54-67. (doi:10.1111/j.17436109.2011.02337.x)

Caulin-Glaser T, Watson CA, Pardi R \& Bender JR 1996 Effects of $17 \beta$-estradiol on cytokine-induced endothelial cell adhesion molecule expression. Journal of Clinical Investigation 98 36-42. (doi:10.1172/ JCI118774)

Ceballos G, Figueroa L, Rubio I, Gallo G, Garcia A, Martinez A, Yañez R, Perez J, Morato T \& Chamorro G 1999 Acute and nongenomic effects of testosterone on isolated and perfused rat heart. Journal of Cardiovascular Pharmacology 33 691-697. (doi:10.1097/00005344-199905000-00003)

Celermajer DS, Sorensen KE, Gooch VM, Spiegelhalter DJ, Miller OI, Sullivan ID, Lloyd JK \& Deanfield JE 1992 Non-invasive detection of endothelial dysfunction in children and adults at risk of atherosclerosis. Lancet 340 1111-1115. (doi:10.1016/0140-6736(92)93147-F)

Channer KS \& Jones TH 2003 Cardiovascular effects of testosterone: implications of the "male menopause"? Heart 89 121-122. (doi:10.1136/heart.89.2.121)

Chen Z, Yuhanna IS, Galcheva-Gargova Z, Karas RH, Mendelsohn ME \& Shaul PW 1999 Estrogen receptor $\alpha$ mediates the nongenomic activation of endothelial nitric oxide synthase by estrogen. Journal of Clinical Investigation 103 401-406. (doi:10.1172/JCI5347)

Chester AH, Jiang C, Borland JA, Yacoub MH \& Collins P 1995 Oestrogen relaxes human epicardial coronary arteries through non-endothelium-dependent mechanisms. Coronary Artery Disease 6 417-422. (doi:10.1097/00019501-199505000-00009)

Chou TM, Sudhir K, Hutchison SJ, Ko E, Amidon TM, Collins P \& Chatterjee K 1996 Testosterone induces dilation of canine coronary conductance and resistance arteries in vivo. Circulation 94 2614-2619. (doi:10.1161/01.CIR.94.10.2614)

Cid MC, Kleinman HK, Grant DS, Schnaper HW, Fauci AS \& Hoffman GS 1994 Estradiol enhances leukocyte binding to tumor necrosis factor (TNF)-stimulated endothelial cells via an increase in TNF-induced adhesion molecules E-selectin, intercellular adhesion molecule type 1, and vascular cell adhesion molecule type 1. Journal of Clinical Investigation 93 17-25. (doi:10.1172/JCI116941)

Clarke MC, Figg N, Maguire JJ, Davenport AP, Goddard M, Littlewood TD \& Bennett MR 2006 Apoptosis of vascular smooth muscle cells induces features of plaque vulnerability in atherosclerosis. Nature Medicine 12 1075-1080. (doi:10.1038/nm1459)

Cohen JC \& Hickman R 1987 Insulin resistance and diminished glucose tolerance in powerlifters ingesting anabolic steroids. Journal of Clinical Endocrinology and Metabolism 64 960-963. (doi:10.1210/jcem-64-5-960)

Corcoran MP, Meydani M, Lichtenstein AH, Schaefer EJ, Dillard A \& Lamon-Flava S 2010 Sex hormone modulation of proinflammatory cytokine and C-reactive protein expression in macrphages from older men and postmenopausal women. Journal of Endocrinology 206 217-224. (doi:10.1677/JOE-10-0057)

Corona G, Petrone L, Fisher AD, Mansani R, Bandini E, Boddi V, Lotti F, Forti G \& Maggi M 2008 Six-month administration of 1\% testosterone gel is able to restore erectile function in hypogonadal patients with erectile dysfunction. Archivio Italiano di Urologia, Andrologia 80 103-108.

Corona G, Mannucci E, Ricca V, Lotti F, Boddi V, Bandini E, Balercia G, Forti G \& Maggi M 2009 The age-related decline of testosterone is associated with different specific symptoms and signs in patients with sexual dysfunction. International Journal of Andrology 32 720-728. (doi:10.1111/j.1365-2605.2009.00952.x)

Corona G, Rastrelli G, Monami M, Guay A, Buvat J, Sforza A, Forti G, Mannucci E \& Maggi M 2011 Hypogonadism as a risk factor for cardiovascular mortality in men: a meta-analytic study. European Journal of Endocrinology 165 687-701. (doi:10.1530/EJE-11-0447)

Corrales JJ, Almeida M, Burgo R, Mories MT, Miralles JM \& Orfao A 2006 Androgen-replacement therapy depresses the ex vivo production of inflammatory cytokines by circulating antigen-presenting cells in aging type-2 diabetic men with partial androgen deficiency. Journal of Endocrinology 189 595-604. (doi:10.1677/joe.1.06779)

Crews JK \& Khalil RA 1999a Antagonistic effects of $17 \beta$-estradiol, progesterone, and testosterone on $\mathrm{Ca}^{2+}$ entry mechanisms of coronary vasoconstriction. Arteriosclerosis, Thrombosis, and Vascular Biology 19 1034-1040. (doi:10.1161/01.ATV.19.4.1034)

Crews JK \& Khalil RA $1999 b$ Gender-specific inhibition of $\mathrm{Ca}^{2+}$ entry mechanisms of arterial vasoconstriction by sex hormones. Clinical and Experimental Pharmacology \& Physiology 26 707-715. (doi:10.1046/j. 1440-1681.1999.03110.x)

Death AK, McGrath KC, Sader MA, Nakhla S, Jessup W, Handelsman DJ \& Celermajer DS 2004 Dihydrotestosterone promotes vascular cell adhesion molecule- 1 expression in male human endothelial cells via a nuclear factor-кB-dependent pathway. Endocrinology 145 1889-1897. (doi:10.1210/en.2003-0789)

Deenadayalu VP, White RE, Stallone JN, Gao X \& Garcia AJ 2001 Testosterone relaxes coronary arteries by opening the largeconductance, calcium-activated potassium channel. American Journal of Physiology. Heart and Circulatory Physiology 281 H1720-H1727.

Demirbag R, Yilmaz R, Ulucay A \& Unlu D 2005 The inverse relationship between thoracic aortic intima media thickness and testosterone level. Endocrine Research 31 335-344. (doi:10.1080/07435800500449494)

Denmeade SR \& Isaacs JT 2002 A history of prostate cancer treatment. Nature Reviews. Cancer 2 389-396. (doi:10.1038/nrc801)

Ding AQ \& Stallone JN 2001 Testosterone-induced relaxation of rat aorta is androgen structure specific and involves $\mathrm{K}^{+}$channel activation. Journal of Applied Physiology 91 2742-2750.

Dockery F, Bulpitt CJ, Donaldson M, Fernandez S \& Rajkumar C 2003a The relationship between androgens and arterial stiffness in older men. Journal of the American Geriatrics Society 51 1627-1632. (doi:10.1046/ j.1532-5415.2003.51515.x)

Dockery F, Bulpitt CJ, Agarwal S, Donaldson M \& Rajkumar C $2003 b$ Testosterone suppression in men with prostate cancer leads to an increase in arterial stiffness and hyperinsulinaemia. Clinical Science $\mathbf{1 0 4}$ 195-201. (doi:10.1042/CS20020209)

Edwards E, Hamilton J \& Duntley S 1939 Testosterone proponate as a therapeutic agent in patients with organic disease of the peripheral vessels. New England Journal of Medicine 220 865. (doi:10.1056/ NEJM193905252202103)

English KM, Jones RD, Jones TH, Morice AH \& Channer KS $2000 a$ Aging reduces the responsiveness of coronary arteries from male Wistar rats to the vasodilatory action of testosterone. Clinical Science 99 77-82. (doi:10.1042/CS19990345)

English KM, Steeds RP, Jones TH, Diver MJ \& Channer KS 2000b Low-dose transdermal testosterone therapy improves angina threshold in men with chronic stable angina: A randomized, double-blind, placebo- 
controlled study. Circulation 102 1906-1911. (doi:10.1161/01.CIR.102. 16.1906)

English KM, Mandour O, Steeds RP, Diver MJ, Jones TH \& Channer KS $2000 c$ Men with coronary artery disease have lower levels of androgens than men with normal coronary angiograms. European Heart Journal 21 890-894. (doi:10.1053/euhj.1999.1873)

English KM, Jones RD, Jones TH, Morice AH \& Channer KS 2001 Gender differences in the vasomotor effects of different steroid hormones in rat pulmonary and coronary arteries. Hormone and Metabolic Research $\mathbf{3 3}$ 645-652. (doi:10.1055/s-2001-18689)

English KM, Jones RD, Jones TH, Morice AH \& Channer KS 2002 Testosterone acts as a coronary vasodilator by a calcium antagonistic action. Journal of Endocrinological Investigation 25 455-458.

Farhat MY, Wolfe R, Vargas R, Foegh ML \& Ramwell PW 1995 Effect of testosterone treatment on vasoconstrictor response of left anterior descending coronary artery in male and female pigs. Journal of Cardiovascular Pharmacology 25 495-500. (doi:10.1097/00005344199503000-00023)

Fernández-Balsells MM, Murad MH, Lane M, Lampropulos JF, Albuquerque F, Mullan RJ, Agrwal N, Elamin MB, Gallegos-Orozco JF, Wang AT et al. 2010 Clinical review 1: adverse effects of testosterone therapy in adult men: a systematic review and meta-analysis. Journal of Clinical Endocrinology and Metabolism 95 2560-2575. (doi:10.1210/jc. 2009-2575)

Franklin SS, Gustin W IV, Wong ND, Larson MG, Weber MA, Kannel WB \& Levy D 1997 Hemodynamic patterns of age-related changes in blood pressure. The Framingham Heart Study. Circulation 96 308-315. (doi:10.1161/01.CIR.96.1.308)

Fukui M, Kitagawa Y, Nakamura N, Kadono M, Mogami S, Hirata C, Ichio N, Wada K, Hasegawa G \& Yoshikawa T 2003 Association between serum testosterone concentration and carotid atherosclerosis in men with type 2 diabetes. Diabetes Care 26 1869-1873. (doi:10.2337/diacare.26. 6.1869)

Gerdes D, Christ M, Haseroth K, Notzon A, Falkenstein E \& Wehling M 2000 Nongenomic actions of steroids - from the laboratory to clinical implications. Journal of Pediatric Endocrinology \& Metabolism 13 853-878.

Goglia L, Tosi V, Sanchez AM, Flamini MI, Fu XD, Zullino S, Genazzani AR \& Simoncini T 2010 Endothelial regulation of eNOS, PAI-1 and t-PA by testosterone and dihydrotestosterone in vitro and in vivo. Molecular Human Reproduction 16 761-769. (doi:10.1093/molehr/gaq049)

Goncharov N, Katsya G, Gaivoronskaya L, Zoloedov V, Uskov V \& Gooren L 2012 Effects of short-term testosterone administration on variables of the metabolic syndrome, in particular aldosterone. Hormone Molecular Biology and Clinical Investigation 12 401-406. (doi:10.1515/hmbci2012-0023)

Greenstein A, Mabjeesh NJ, Sofer M, Kaver I, Matzkin H \& Chen J 2005 Does sildenafil combined with testosterone gel improve erectile dysfunction in hypogonadal men in whom testosterone therapy alone failed. Journal of Urology 173 530-532.

Guay AT, Perez JB, Jacobson J \& Newton RA 2001 Efficacy and safety of sildenafil citrate for treatment of erectile dysfunction in a population with associated organic risk factors. Journal of Andrology 22 793-797.

Haddad RM, Kennedy CC, Caples SM, Tracz MJ, Boloña ER, Sideras K, Uraga MV, Erwin PJ \& Montori VM 2007 Testosterone and cardiovascular risk in men: a systematic review and meta-analysis of randomized placebo-controlled trials. Mayo Clinic Proceedings 82 29-39.

Haider A, Gooren LJ, Padungtod P \& Saad F 2009 Improvement of the metabolic syndrome and of non-alcoholic liver steatosis upon treatment of hypogonadal elderly men with parenteral testosterone undecanoate. Experimental and Clinical Endocrinology \& Diabetes 118 167-171. (doi:10.1055/s-0029-1202774)

Hak AE, Witteman JC, de Jong FH, Geerlings MI, Hofman A \& Pols HA 2002 Low levels of endogenous androgens increase the risk of atherosclerosis in elderly men: the Rotterdam study. Journal of Clinical Endocrinology and Metabolism 87 3632-3639. (doi:10.1210/jc.87.8.3632)
Hall J, Jones RD, Jones TH, Channer KS \& Peers C 2006 Selective inhibition of L-type $\mathrm{Ca}^{2+}$ channels in A7r5 cells by physiological levels of testosterone. Endocrinology 147 2675-2680. (doi:10.1210/ en.2005-1243)

Hamm L 1942 Testosterone propionate in the treatment of angina pectoris. Journal of Clinical Endocrinology and Metabolism 2 325-328. (doi:10.1210/jcem-2-5-325)

Harada N, Sasano H, Murakami H, Ohkuma T, Nagura H \& Takagi Y 1999 Localized expression of aromatase in human vascular tissues. Circulation Research 84 1285-1291. (doi:10.1161/01.RES.84.11.1285)

Hatakeyama H, Nishizawa M, Nakagawa A, Nakano S, Kigoshi T \& Uchida K 2002 Testosterone inhibits tumor necrosis factor- $\alpha$-induced vascular cell adhesion molecule-1 expression in human aortic endothelial cells. FEBS Letters 530 129-132. (doi:10.1016/S0014-5793(02)03440-3)

Heinlein CA \& Chang C 2002 The roles of androgen receptors and androgen-binding proteins in nongenomic androgen actions. Molecular Endocrinology 16 2181-2187. (doi:10.1210/me.2002-0070)

Herman SM, Robinson JT, McCredie RJ, Adams MR, Boyer MJ \& Celermajer DS 1997 Androgen deprivation is associated with enhanced endothelium-dependent dilatation in adult men. Arteriosclerosis, Thrombosis, and Vascular Biology 17 2004-2009. (doi:10.1161/01.ATV. 17.10.2004)

Honda H, Unemoto T \& Kogo H 1999 Different mechanisms for testosterone-induced relaxation of aorta between normotensive and spontaneously hypertensive rats. Hypertension 34 1232-1236. (doi:10.1161/01.HYP.34.6.1232)

Hou J, Baichwal V \& Cao Z 1994 Regulatory elements and transcription factors controlling basal and cytokine-induced expression of the gene encoding intercellular adhesion molecule 1. PNAS 91 11641-11645. (doi:10.1073/pnas.91.24.11641)

Hougaku H, Fleg JL, Najjar SS, Lakatta EG, Harman SM, Blackman MR \& Metter EJ 2006 Relationship between androgenic hormones and arterial stiffness, based on longitudinal hormone measurements. American Journal of Physiology. Endocrinology and Metabolism 290 E234-E242. (doi:10.1152/ajpendo.00059.2005)

Hughes GS, Mathur RS \& Margolius HS 1989 Sex steroid hormones are altered in essential hypertension. Journal of Hypertension 7 181-187. (doi:10.1097/00004872-198903000-00003)

Ikeda Y, Aihara K, Yoshida S, Sato T, Yagi S, Iwase T, Sumitomo Y, Ise T, Ishikawa K, Azuma $\mathrm{H}$ et al. 2009 Androgen-androgen receptor system protects against angiotensin II-induced vascular remodeling. Endocrinology 150 2857-2864. (doi:10.1210/en.2008-1254)

Jackson G 2012 Erectile dysfunction and coronary disease: evaluating the link. Maturitas 72 263-264. (doi:10.1016/j.maturitas.2012.03.012)

Jaffe MD 1977 Effect of testosterone cypionate on postexercise ST segment depression. British Heart Journal 39 1217-1222. (doi:10.1136/ hrt.39.11.1217)

Jiang P, Xu J, Zheng S, Huang J, Xiang Q, Fu X \& Wang T 2010 17 $\beta$-Estradiol down-regulates lipopolysaccharide-induced MCP-1 production and cell migration in vascular smooth muscle cells. Journal of Molecular Endocrinology 45 87-97. (doi:10.1677/JME-09-0166)

Johannsson G, Gibney J, Wolthers T, Leung KC \& Ho KK 2005 Independent and combined effects of testosterone and growth hormone on extracellular water in hypopituitary men. Journal of Clinical Endocrinology and Metabolism 90 3989-3994. (doi:10.1210/jc.2005-0553)

Johnson JL 2007 Matrix metalloproteinases: influence on smooth muscle cells and atherosclerotic plaque stability. Expert Review of Cardiovascular Therapy 5 265-282. (doi:10.1586/14779072.5.2.265)

Jones RD, English KM, Pugh PJ, Morice AH, Jones TH \& Channer KS 2002 Pulmonary vasodilatory action of testosterone: evidence of a calcium antagonistic action. Journal of Cardiovascular Pharmacology 39 814-823. (doi:10.1097/00005344-200206000-00006)

Jones RD, Pugh PJ, Hall J, Channer KS \& Jones TH 2003a Altered circulating hormone levels, endothelial function and vascular reactivity in the testicular feminised mouse. European Journal of Endocrinology 148 111-120. (doi:10.1530/eje.0.1480111) 
Jones RD, Pugh PJ, Jones TH \& Channer KS 2003b The vasodilatory action of testosterone: a potassium-channel opening or a calcium antagonistic action? British Journal of Pharmacology 138 733-744. (doi:10.1038/sj. bjp.0705141)

Jones RD, Ruban LN, Morton IE, Roberts SA, English KM, Channer KS \& Jones TH 2003c Testosterone inhibits the prostaglandin $\mathrm{F}_{2 \alpha}$-mediated increase in intracellular calcium in A7r5 aortic smooth muscle cells: evidence of an antagonistic action upon store-operated calcium channels. Journal of Endocrinology 178 381-393. (doi:10.1677/joe.0. 1780381)

Jones RD, English KM, Jones TH \& Channer KS 2004a Testosterone-induced coronary vasodilatation occurs via a non-genomic mechanism: evidence of a direct calcium antagonism action. Clinical Science $\mathbf{1 0 7}$ 149-158. (doi:10.1042/CS20030386)

Jones RD, Jones TH \& Channer KS 2004b The influence of testosterone upon vascular reactivity. European Journal of Endocrinology 151 29-37. (doi:10.1530/eje.0.1510029)

Jones RD, Rowell KO, Pugh PJ, Shorthouse AJ, Adam IA, Vaughan R, Rocco G, Hopkinson DN, Channer KS \& Jones TH 2004c Testosteroneinduced vasodilatation of isolated human mesenteric and pulmonary resistance arteries is independent of the vascular endothelium. Endocrine Abstracts 7 P66.

Jones TH 2010a Testosterone deficiency: a risk factor for cardiovascular disease? Trends in Endocrinology and Metabolism 21 496-503. (doi:10.1016/j.tem.2010.03.002)

Jones TH $2010 b$ Effects of testosterone on type 2 diabetes and components of the metabolic syndrome. Journal of Diabetes 2 146-156. (doi:10.1111/ j.1753-0407.2010.00085.x)

Jones TH \& Saad F 2009 The effects of testosterone on risk factors for and the mediators of, the atherosclerotic process. Atherosclerosis $\mathbf{2 0 7}$ 318-327. (doi:10.1016/j.atherosclerosis.2009.04.016)

Jones TH 2011 Cardiovascular risk during androgen deprivation therapy for prostate cancer. British Medical Journal 342 d3105.

Kalaitzidis D \& Gilmore TD 2005 Transcription factor cross-talk: the estrogen receptor and NF-кB. Trends in Endocrinology and Metabolism 16 46-52. (doi:10.1016/j.tem.2005.01.004)

Kalinchenko SY, Kozlov GI, Gontcharov NP \& Katsiya GV 2003 Oral testosterone undecanoate reverses erectile dysfunction associated with diabetes mellitus in patients failing on sildenafil citrate therapy alone. Aging Male 6 94-99.

Kalinchenko SY, Tishova YA, Mskhalaya GJ, Gooren LJ, Giltay EJ \& Saad F 2010 Effects of testosterone supplementation on markers of the metabolic syndrome and inflammation in hypogonadal men with the metabolic syndrome: the double-blinded placebo-controlled Moscow study. Clinical Endocrinology 73 602-612. (doi:10.1111/j.1365-2265. 2010.03845.x)

Kanda N, Tsuchida T \& Tamaki K 1996 Testosterone inhibits immunoglobulin production by human peripheral blood mononuclear cells. Clinical and Experimental Immunology 106 410-415. (doi:10.1046/ j.1365-2249.1996.d01-842.x)

Kang SM, Jang Y, Kim JY, Chung N, Cho SY, Chae JS \& Lee JH 2002 Effect of oral administration of testosterone on brachial arterial vasoreactivity in men with coronary artery disease. American Journal of Cardiology $\mathbf{8 9}$ 862-864. (doi:10.1016/S0002-9149(02)02202-6)

Kapoor D, Clarke S, Channer KS \& Jones TH 2007 The effect of testosterone replacement therapy on adipocytokines and C-reactive protein in hypogonadal men with type 2 diabetes. European Journal of Endocrinology 156 595-602. (doi:10.1530/EJE-06-0737)

Kaszubska W, Hooft van Huijsduijnen R, Ghersa P, DeRaemy-Schenk AM, Chen BP, Hai T, DeLamarter JF \& Whelan J 1993 Cyclic AMPindependent ATF family members interact with NF- $\mathrm{KB}$ and function in the activation of the E-selectin promoter in response to cytokines. Molecular and Cellular Biology 13 7180-7190.

Keating NL, O'Malley AJ \& Smith MR 2006 Diabetes and cardiovascular disease during androgen deprivation therapy for prostate cancer.
Journal of Clinical Oncology 24 4448-4456. (doi:10.1200/JCO. 2006.06.2497)

Kelly DM \& Jones TH 2013 Testosterone: a metabolic hormone in health and disease. Journal of Endocrinology 217 R25-R45. (doi:10.1530/ JOE-12-0455)

Kelly DM, Sellers DJ, Woodroofe MN, Jones TH \& Channer KS 2012 Effect of testosterone on inflammatory markers in the development of early atherogenesis in the testicular-feminized mouse model. Endocrine Research. In press. (doi:10.3109/07435800.2012.735307)

Kenny AM, Bellantonio S, Gruman CA, Acosta RD \& Prestwood KM 2002 Effects of transdermal testosterone on cognitive function and health perception in older men with low bioavailable testosterone levels. Journals of Gerontology. Series A, Biological Sciences and Medical Sciences $\mathbf{5 7}$ M321-M325. (doi:10.1093/gerona/57.5.M321)

Khaw KT \& Barrett-Connor E 1988 Blood pressure and endogenous testosterone in men: an inverse relationship. Journal of Hypertension $\mathbf{6}$ 329-332. (doi:10.1097/00004872-198804000-00010)

Khaw KT, Dowsett M, Folkerd E, Bingham S, Wareham N, Luben R, Welch A \& Day N 2007 Endogenous testosterone and mortality due to all causes, cardiovascular disease, and cancer in men: European prospective investigation into cancer in Norfolk (EPIC-Norfolk) Prospective Population Study. Circulation 116 2694-2701. (doi:10.1161/CIRCULATIONAHA.107.719005)

Khosla S, Atkinson EJ, Dunstan CR \& O'Fallon WM 2002 Effect of estrogen versus testosterone on circulating osteoprotegerin and other cytokine levels in normal elderly men. Journal of Clinical Endocrinology and Metabolism 87 1550-1554. (doi:10.1210/jc.87.4.1550)

Kuvin JT, Patel AR, Sliney KA, Pandian NG, Rand WM, Udelson JE \& Karas RH 2001 Peripheral vascular endothelial function testing as a noninvasive indicator of coronary artery disease. Journal of the American College of Cardiology 38 1843-1849. (doi:10.1016/S07351097(01)01657-6)

Lanfranco F, Zitzmann M, Simoni M \& Nieschlag E 2004 Serum adiponectin levels in hypogonadal males: influence of testosterone replacement therapy. Clinical Endocrinology 60 500-507. (doi:10.1111/ j.1365-2265.2004.02007.x)

Laughlin GA, Barrett-Connor E \& Bergstrom J 2008 Low serum testosterone and mortality in older men. Journal of Clinical Endocrinology and Metabolism 93 68-75. (doi:10.1210/jc.2007-1792)

Lee M 2011 Focus on phosphodiesterase inhibitors for the treatment of erectile dysfunction in older men. Clinical Therapeutics 33 1590-1608. (doi:10.1016/j.clinthera.2011.09.029)

Lesser MA 1942 The treatment of angina pectoris with testosterone propionate; preliminary report. New England Journal of Medicine 226 51-54. (doi:10.1056/NEJM194201082260203)

Levine GN, D'Amico AV, Berger P, Clark PE, Eckel RH, Keating NL, Milani RV, Sagalowsky AI, Smith MR \& Zakai N 2010 Androgen deprivation therapy in prostate cancer and cardiovascular risk: a science advisory from the American Heart Association, American Cancer Society and American Urological Association: endorsed by the American Society for Radiation Oncology. Circulation 121 833-840. (doi:10.1161/CIRCULATIONAHA.109.192695)

Lu Y, Fu Y, Ge Y, Juncos LA, Reckelhoff JF \& Liu R 2012 The vasodilatory effect of testosterone on renal afferent arterioles. Gender Medicine $\mathbf{9}$ 103-111. (doi:10.1016/j.genm.2012.02.003)

Lugg JA, Rajfer J \& González-Cadavid NF 1995 Dihydrotestosterone is the active androgen in the maintenance of nitric oxide-mediated penile erection in the rat. Endocrinology 136 1495-1501. (doi:10.1210/ en.136.4.1495)

Ly LP, Jimenez M, Zhuang TN, Celermajer DS, Conway AJ \& Handelsman DJ 2001 A double-blind, placebo-controlled, randomized clinical trial of transdermal dihydrotestosterone gel on muscular strength, mobility, and quality of life in older men with partial androgen deficiency. Journal of Clinical Endocrinology and Metabolism 86 4078-4088. (doi:10.1210/jc.86.9.4078) http://joe.endocrinology-journals.org DOI: 10.1530/JOE-12-0582
() 2013 Society for Endocrinology Printed in Great Britain 
Maggio M, Basaria S, Ble A, Lauretani F, Bandinelli S, Ceda GP, Valenti G, Ling SM \& Ferrucci L 2006 Correlation between testosterone and the inflammatory marker soluble interleukin-6 receptor in older men. Journal of Clinical Endocrinology and Metabolism 91 345-347. (doi:10.1210/jc.2005-1097)

Mäkinen J, Järvisalo MJ, Pöllänen P, Perheentupa A, Irjala K, Koskenvuo M, Mäkinen J, Huhtaniemi I \& Raitakari OT 2005 Increased carotid atherosclerosis in andropausal middle-aged men. Journal of the American College of Cardiology 45 1603-1608. (doi:10.1016/ j.jacc.2005.01.052)

Malkin CJ, Pugh PJ, Jones RD, Kapoor D, Channer KS \& Jones TH 2004a The effect of testosterone replacement on endogenous inflammatory cytokines and lipid profiles in hypogonadal men. Journal of Clinical Endocrinology and Metabolism 89 3313-3318. (doi:10.1210/jc.2003031069)

Malkin CJ, Pugh PJ, Morris PD, Kerry KE, Jones RD, Jones TH \& Channer KS $2004 b$ Testosterone replacement in hypogonadal men with angina improves ischaemic threshold and quality of life. Heart 90 871-876. (doi:10.1136/hrt.2003.021121)

Malkin CJ, Jones RD, Jones TH \& Channer KS 2006a Effect of testosterone on ex vivo vascular reactivity in man. Clinical Science 111 265-274. (doi:10.1042/CS20050354)

Malkin CJ, Pugh PJ, West JN, van Beek EJ, Jones TH \& Channer KS $2006 b$ Testosterone therapy in men with moderate severity heart failure: a double-blind randomized placebo controlled trial. European Heart Journal 27 57-64. (doi:10.1093/eurheartj/ehi443)

Malkin CJ, Pugh PJ, Morris PD, Asif S, Jones TH \& Channer KS 2010 Low serum testosterone and increased mortality in men with coronary heart disease. Heart 96 1821-1825. (doi:10.1136/hrt.2010.195412)

Mancini A, Leone E, Festa R, Grande G, Silvestrini A, de Marinis L, Pontecorvi A, Maira G, Littarru GP \& Meucci E 2008 Effects of testosterone on antioxidant systems in male secondary hypogonadism. Journal of Andrology 29 622-629. (doi:10.2164/jandrol.107.004838)

Manolakou P, Angelopoulou R, Bakoyiannis C \& Bastounis E 2009 The effects of endogenous and exogenous androgens on cardiovascular disease risk factors and progression. Reproductive Biology and Endocrinology 7 44. (doi:10.1186/1477-7827-7-44)

Mathur A, Malkin C, Saeed B, Muthusamy R, Jones TH \& Channer K 2009 Long-term benefits of testosterone replacement therapy on angina threshold and atheroma in men. European Journal of Endocrinology 161 443-449. (doi:10.1530/EJE-09-0092)

McCrohon JA, Jessup W, Handelsman DJ \& Celermajer DS 1999 Androgen exposure increases human monocyte adhesion to vascular endothelium and endothelial cell expression of vascular cell adhesion molecule-1. Circulation 99 2317-2322. (doi:10.1161/01.CIR.99.17. 2317)

McKay LI \& Cidlowski JA 1998 Cross-talk between nuclear factor- $\kappa$ B and the steroid hormone receptors: mechanisms of mutual antagonism. Molecular Endocrinology 12 45-56. (doi:10.1210/me.12.1.45)

Miller MR \& Megson IL 2007 Recent developments in nitric oxide donor drugs. British Journal of Pharmacology 151 305-321. (doi:10.1038/sj.bjp. 0707224)

Miller VM \& Mulvagh SL 2007 Sex steroids and endothelial function: translating basic science to clinical practice. Trends in Pharmacological Sciences 28 263-270. (doi:10.1016/j.tips.2007.04.004)

Mills TM \& Lewis RW 1999 The role of andorgens in the erectile response: a 1999 perspective. Molecular Urology 3 75-86.

Mills TM, Dai Y, Stopper VS \& Lewis RW 1999a Androgenic maintenance of the erectile response in the rat. Steroids 64 605-609. (doi:10.1016/ S0039-128X(99)00040-9)

Mills TM, Lewis RW \& Stopper VS 1999b Androgenic maintenance of inflow and veno-occlusion during erection in the rat. Biology of Reproduction 59 1413-1418. (doi:10.1095/biolreprod59.6.1413)

Montaño LM, Calixto E, Figueroa A, Flores-Soto E, Carbajal V \& Perusquía M 2008 Relaxation of androgens on rat thoracic aorta: testosterone concentration dependent agonist/antagonist L-type $\mathrm{Ca}^{2+}$ channel activity, and $5 \beta$-dihydrotestosterone restricted to L-type $\mathrm{Ca}^{2+}$ channel blockade. Endocrinology 149 2517-2526. (doi:10.1210/en. 2007-1288)

Morelli A, Filippi S, Mancina R, Luconi M, Vignozzi L, Marini M, Orlando C, Vannelli GB, Aversa A, Natali A et al. 2004 Androgens regulate phosphodiesterase type 5 expression and functional activity in corpora cavernosa. Endocrinology 145 2253-2263. (doi:10.1210/en.2003-1699)

Morgentaler A \& Schulman C 2009 Testosterone and prostate safety. Frontiers of Hormone Research 37 197-203.

Mukherjee TK, Dinh H, Chaudhuri G \& Nathan L 2002 Testosterone attenuates expression of vascular cell adhesion molecule- 1 by conversion to estradiol by aromatase in endothelial cells: implications in atherosclerosis. PNAS 99 4055-4060. (doi:10.1073/pnas.052703199)

Muller M, van den Beld AW, Bots ML, Grobbee DE, Lamberts SW \& van der Schouw YT 2004 Endogenous sex hormones and progression of carotid atherosclerosis in elderly men. Circulation 109 2074-2079. (doi:10.1161/01.CIR.0000125854.51637.06)

Murphy JG \& Khalil RA 1999 Decreased $(\mathrm{Ca}(2+))(\mathrm{i})$ during inhibition of coronary smooth muscle contraction by $17 \beta$-estradiol, progesterone, and testosterone. Journal of Pharmacology and Experimental Therapeutics $29144-52$.

Nakagami F, Nakagami H, Osako MK, Iwabayashi M, Taniyama Y, Doi T, Shimizu H, Shimamura M, Rakugi H \& Morishita R 2010 Estrogen attenuates vascular remodeling in Lp(a) transgenic mice. Atherosclerosis 211 41-47. (doi:10.1016/j.atherosclerosis.2010.01.016)

Nakamura Y, Suzuki T, Igarashi K, Kanno J, Furukawa T, Tazawa C, Fujishima F, Miura I, Ando T, Moriyama N et al. 2006 PTOV1: a novel testosterone-induced atherogenic gene in human aorta. Journal of Pathology 209 522-531. (doi:10.1002/path.1993)

Nathan L, Shi W, Dinh H, Mukherjee TK, Wang X, Lusis AJ \& Chaudhuri G 2001 Testosterone inhibits early atherogenesis by conversion to estradiol: critical role of aromatase. PNAS 98 3589-3593. (doi:10.1073/ pnas.051003698)

Navarro-Dorado J, Orensanz LM, Recio P, Bustamante S, Benedito S, Martínez AC, García-Sacristán A, Prieto D \& Hernández M 2008 Mechanisms involved in testosterone-induced vasodilatation in pig prostatic small arteries. Life Sciences 83 569-573. (doi:10.1016/j.lfs. 2008.08.009)

Neish AS, Williams AJ, Palmer HJ, Whitley MZ \& Collins T 1992 Functional analysis of the human vascular cell adhesion molecule 1 promoter. Journal of Experimental Medicine 176 1583-1593. (doi:10.1084/jem.176. 6.1583)

Nettleship JE, Jones TH, Channer KS \& Jones RD 2007a Physiological testosterone replacement therapy attenuates fatty streak formation and improves high-density lipoprotein cholesterol in the Tfm mouse: an effect that is independent of the classic androgen receptor. Circulation 116 2427-2434. (doi:10.1161/CIRCULATIONAHA.107.708768)

Nettleship JE, Pugh PJ, Channer KS, Jones T \& Jones RD 2007 $b$ Inverse relationship between serum levels of interleukin-1 $\beta$ and testosterone in men with stable coronary artery disease. Hormone and Metabolic Research 39 366-371. (doi:10.1055/s-2007-976543)

Ng MK, Liu PY, Williams AJ, Nakhla S, Ly LP, Handelsman DJ \& Celermajer DS 2002 Prospective study of effect of androgens on serum inflammatory markers in men. Arteriosclerosis, Thrombosis, and Vascular Biology 22 1136-1141. (doi:10.1161/01.ATV.0000022167.80130.A6)

Nguyen PL, Je Y, Schutz FA, Hoffman KE, Hu JC, Parekh A, Beckman JA \& Choueiri TK 2011 Association of androgen deprivation therapy with cardiovascular death in patients with prostate cancer: a meta-analysis of randomized trials. Journal of the American Medical Association 306 2359-2366. (doi:10.1001/jama.2011.1745)

Norata GD, Tibolla G, Seccomandi PM, Poletti A \& Catapano AL 2006 Dihydrotestosterone decreases tumor necrosis factor- $\alpha$ and lipopolysaccharide-induced inflammatory response in human endothelial cells. Journal of Clinical Endocrinology and Metabolism 91 546-554. (doi:10.1210/jc.2005-1664) 
Norata GD, Cattaneo P, Poletti A \& Catapano AL 2010 The androgen derivative $5 \alpha$-androstane-3 $\beta, 17 \beta$-diol inhibits tumor necrosis factor $\alpha$ and lipopolysaccharide induced inflammatory response in human endothelial cells and in mice aorta. Atherosclerosis 212 100-106. (doi:10.1016/j.atherosclerosis.2010.05.015)

Ohlsson C, Barrett-Connor E, Bhasin S, Orwoll E, Labrie F, Karlsson MK, Ljunggren O, Vandenput L, Mellström D \& Tivesten A 2011 High serum testosterone is associated with reduced risk of cardiovascular events in elderly men. The MrOS (Osteoporotic Fractures in Men) study in Sweden. Journal of the American College of Cardiology 58 1674-1681. (doi:10.1016/j.jacc.2011.07.019)

Ong PJ, Patrizi G, Chong WC, Webb CM, Hayward CS \& Collins P 2000 Testosterone enhances flow-mediated brachial artery reactivity in men with coronary artery disease. American Journal of Cardiology 85 269-272. (doi:10.1016/S0002-9149(99)00630-X)

Osterlund KL, Handa RJ \& Gonzales RJ 2010 Dihydrotestosterone alters cyclooxygenase-2 levels in human coronary artery smooth muscle cells. American Journal of Physiology. Endocrinology and Metabolism 298 E838-E845. (doi:10.1152/ajpendo.00693.2009)

Ota H, Akishita M, Akiyoshi T, Kahyo T, Setou M, Ogawa S, Iijima K, Eto M \& Ouchi Y 2012 Testosterone deficiency accelerates neuronal and vascular aging of SAMP8 mice: protective role of eNOS and SIRT1. PLoS ONE 7 e29598. (doi:10.1371/journal.pone.0029598)

Page ST, Herbst KL, Amory JK, Coviello AD, Anawalt BD, Matsumoto AM \& Bremner WJ 2005 Testosterone administration suppresses adiponectin levels in men. Journal of Andrology 26 85-92.

Penson DF, Ng C, Cai L, Rajfer J \& González-Cadavid NF 1996 Androgen and pituitary control of penile nitric oxide synthase and erectile function in the rat. Biology of Reproduction 55 567-574. (doi:10.1095/ biolreprod55.3.567)

Perusquía M \& Villalón CM 1999 Possible role of $\mathrm{Ca}^{2+}$ channels in the vasodilating effect of $5 \beta$-dihydrotestosterone in rat aorta. European Journal of Pharmacology 371 169-178. (doi:10.1016/S00142999(99)00161-2)

Perusquía M, Hernández R, Morales MA, Campos MG \& Villalón CM 1996 Role of endothelium in the vasodilating effect of progestins and androgens on the rat thoracic aorta. General Pharmacology 27 181-185. (doi:10.1016/0306-3623(95)00091-7)

Perusquía M, Navarrete E, González L \& Villalón CM 2007 The modulatory role of androgens and progestins in the induction of vasorelaxation in human umbilical artery. Life Sciences 81 993-1002. (doi:10.1016/j.lfs. 2007.07.024)

Phillips GB, Jing TY, Resnick LM, Barbagallo M, Laragh JH \& Sealey JE 1993 Sex hormones and hemostatic risk factors for coronary heart disease in men with hypertension. Journal of Hypertension 11 699-702. (doi:10.1097/00004872-199307000-00003)

Ponikowska B, Jankowska EA, Maj J, Wegrzynowska-Teodorczyk K, Biel B, Reczuch K, Borodulin-Nadzieja L, Banasiak W \& Ponikowski P 2010 Gonadal and adrenal androgen deficiencies as independent predictors of increased cardiovascular mortality in men with type II diabetes mellitus and stable coronary artery disease. International Journal of Cardiology 143 343-348. (doi:10.1016/j.ijcard. 2009.03.072)

Pugh PJ, Jones RD, Jones TH \& Channer KS 2002 Intrinsic responses of rat coronary arteries in vitro: influence of testosterone, calcium, and effective transmural pressure. Endocrine 19 155-161. (doi:10.1385/ ENDO:19:2:155)

Pugh PJ, Jones TH \& Channer KS 2003 Acute haemodynamic effects of testosterone in men with chronic heart failure. European Heart Journal 24 909-915. (doi:10.1016/S0195-668X(03)00083-6)

Pugh PJ, Jones RD, Malkin CJ, Hall J, Nettleship JE, Kerry KE, Jones TH \& Channer KS 2005 Physiologic testosterone therapy has no effect on serum levels of tumour necrosis factor- $\alpha$ in men with chronic heart failure. Endocrine Research 31 271-283. (doi:10.1080/ 07435800500406205)
Quan A, Teoh H \& Man RY 1999 Acute exposure to a low level of testosterone impairs relaxation in porcine coronary arteries. Clinical and Experimental Pharmacology \& Physiology 26 830-832. (doi:10.1046/j. 1440-1681.1999.03138.x)

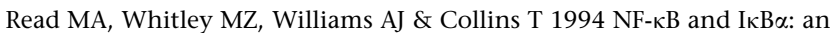
inducible regulatory system in endothelial activation. Journal of Experimental Medicine 179 503-512. (doi:10.1084/jem.179.2.503)

Reckelhoff JF, Zhang H \& Granger JP 1998 Testosterone exacerbates hypertension and reduces pressure-natriuresis in male spontaneously hypertensive rats. Hypertension 31 435-439. (doi:10.1161/01.HYP.31. 1.435)

Reckelhoff JF, Yanes LL, Iliescu R, Fortepiani LA \& Granger JP 2005 Testosterone supplementation in aging men and women: possible impact on cardiovascular-renal disease. American Journal of Physiology. Renal Physiology 289 F941-F948. (doi:10.1152/ajprenal. 00034.2005)

Rivard A \& Andrés V 2000 Vascular smooth muscle cell proliferation in the pathogenesis of atherosclerotic cardiovascular diseases. Histology and Histopathology 15 557-571.

Rosano GM, Leonardo F, Pagnotta P, Pelliccia F, Panina G, Cerquetani E, della Monica PL, Bonfigli B, Volpe M \& Chierchia SL 1999 Acute anti-ischemic effect of testosterone in men with coronary artery disease. Circulation 99 1666-1670. (doi:10.1161/01.CIR.99.13.1666)

Rosner W, Hryb DJ, Khan MS, Nakhla AM \& Romas NA 1999 Sex hormonebinding globulin mediates steroid hormone signal transduction at the plasma membrane. Journal of Steroid Biochemistry and Molecular Biology 69 481-485. (doi:10.1016/S0960-0760(99)00070-9)

Rowell KO, Hall J, Pugh PJ, Jones TH, Channer KS \& Jones RD 2009 Testosterone acts as an efficacious vasodilator in isolated human pulmonary arteries and veins: evidence for a biphasic effect at physiological and supra-physiological concentrations. Journal of Endocrinological Investigation 32 718-723.

Sader MA, Griffiths KA, Skilton MR, Wishart SM, Handelsman DJ \& Celermajer DS 2003 Physiological testosterone replacement and arterial endothelial function in men. Clinical Endocrinology 59 62-67. (doi:10.1046/j.1365-2265.2003.01796.x)

Salom JB, Burguete MC, Pérez-Asensio FJ, Torregrosa G \& Alborch E 2001 Relaxant effects of 17 - $\beta$-estradiol in cerebral arteries through $\mathrm{Ca}(2+)$ entry inhibition. Journal of Cerebral Blood Flow and Metabolism 21 422-429.

Schrör K, Morinelli TA, Masuda A, Matsuda K, Mathur RS \& Halushka PV 1994 Testosterone treatment enhances thromboxane A2 mimetic induced coronary artery vasoconstriction in guinea pigs. European Journal of Clinical Investigation 24 50-52. (doi:10.1111/j.1365-2362. 1994.tb02059.x)

Scragg JL, Jones RD, Channer KS, Jones TH \& Peers C 2004 Testosterone is a potent inhibitor of L-type $\mathrm{Ca}^{2+}$ channels. Biochemical and Biophysical Research Communications 318 503-506. (doi:10.1016/ j.bbrc.2004.04.054)

Scragg JL, Dallas ML \& Peers C 2007 Molecular requirements for L-type $\mathrm{Ca}^{2+}$ channel blockade by testosterone. Cell Calcium 42 11-15. (doi:10.1016/j.ceca.2006.11.003)

Seyrek M, Yildiz O, Ulusoy HB \& Yildirim V 2007 Testosterone relaxes isolated human radial artery by potassium channel opening action. Journal of Pharmacological Sciences 103 309-316. (doi:10.1254/ jphs.FP0060883)

Shabsigh R, Kaufman J, Steidle J \& Padma-Nathan H 2004 Randomized study of testosterone gel as adjunctive therapy to sildenafil in hypogonadal men with erectile dysfunction who do not respond to sildenafil alone. Journal of Urology 172 658-663.

Simon D, Charles MA, Nahoul K, Orssaud G, Kremski J, Hully V, Joubert E, Papoz L \& Eschwege E 1997 Association between plasma total testosterone and cardiovascular risk factors in healthy adult men: the Telecom Study. Journal of Clinical Endocrinology and Metabolism $\mathbf{8 2}$ 682-685. (doi:10.1210/jc.82.2.682) 
Simoncini T, Hafezi-Moghadam A, Brazil DP, Ley K, Chin WW \& Liao JK $2000 a$ Interaction of oestrogen receptor with the regulatory subunit of phosphatidylinositol-3-OH kinase. Nature 407 538-541. (doi:10.1038/ 35035131)

Simoncini T, Maffei S, Basta G, Barsacchi G, Genazzani AR, Liao JK \& De Caterina R $2000 b$ Estrogens and glucocorticoids inhibit endothelial vascular cell adhesion molecule- 1 expression by different transcriptional mechanisms. Circulation Research 87 19-25. (doi:10.1161/ 01.RES.87.1.19)

Smith JC, Bennett S, Evans LM, Kynaston HG, Parmar M, Mason MD, Cockcroft JR, Scanlon MF \& Davies JS 2001 The effects of induced hypogonadism on arterial stiffness, body composition, and metabolic parameters in males with prostate cancer. Journal of Clinical Endocrinology and Metabolism 86 4261-4267. (doi:10.1210/jc.86.9.4261)

Smith AM, Bennett RT, Jones TH, Cowen ME, Channer KS \& Jones RD 2008 Characterization of the vasodilatory action of testosterone in the human pulmonary circulation. Vascular Health and Risk Management 4 1459-1466.

Sorensen KE, Celermajer DS, Spiegelhalter DJ, Georgakopoulos D, Robinson J, Thomas O \& Deanfield JE 1995 Non-invasive measurement of human endothelium dependent arterial responses: accuracy and reproducibility. British Heart Journal 74 247-253. (doi:10.1136/hrt.74.3.247)

Srinivas-Shankar U, Roberts SA, Connolly MJ, Connell MDLO, Adams JE, Oldham JA \& Wu FCW 2010 Effects of testosterone on muscle strength, physical function, body composition, and quality of life in intermediate-Frail and Frail elderly men: a randomized, double-blind, placebo-controlled study. Journal of Clinical Endocrinology and Metabolism 95 639-650. (doi:10.1210/jc.2009-1251)

Stein B \& Yang MX 1995 Repression of the interleukin-6 promoter by estrogen receptor is mediated by NF- $\mathrm{BB}$ and C/EBP $\beta$. Molecular and Cellular Biology 15 4971-4979.

Stigher LH \& Tulgan J 1943 Treatment of angina pectoris by testosterone propionate. New York State Journal of Medicine 43 1424-1428.

Sullivan ML, Martinez CM, Gennis P \& Gallagher EJ 1998 The cardiac toxicity of anabolic steroids. Progress in Cardiovascular Diseases 41 1-15. (doi:10.1016/S0033-0620(98)80019-4)

Supakar PC, Jung MH, Song CS, Chatterjee B \& Roy AK 1995 Nuclear factor $\kappa \mathrm{B}$ functions as a negative regulator for the rat androgen receptor gene and NF- $\kappa \mathrm{B}$ activity increases during the age-dependent desensitization of the liver. Journal of Biological Chemistry 270 837-842. (doi:10.1074/ jbc.270.2.837)

Svartberg J, von Mühlen D, Schirmer H, Barrett-Connor E, Sundfjord J \& Jorde R 2004 Association of endogenous testosterone with blood pressure and left ventricular mass in men. The Tromsø Study. European Journal of Endocrinology 150 65-71. (doi:10.1530/eje.0.1500065)

Svartberg J, von Mühlen D, Mathiesen E, Joakimsen O, Bønaa KH \& Stensland-Bugge E 2006 Low testosterone levels are associated with carotid atherosclerosis in men. Journal of Internal Medicine 259 576-582. (doi:10.1111/j.1365-2796.2006.01637.x)

Takase B, Uehata A, Akima T, Nagai T, Nishioka T, Hamabe A, Satomura K, Ohsuzu F \& Kurita A 1998 Endothelium-dependent flow-mediated vasodilation in coronary and brachial arteries in suspected coronary artery disease. American Journal of Cardiology 82 1535-1539. (doi:10.1016/S0002-9149(98)00702-4)

Teoh H, Quan A \& Man RY 2000a Acute impairment of relaxation by low levels of testosterone in porcine coronary arteries. Cardiovascular Research 45 1010-1018. (doi:10.1016/S0008-6363(99)00398-3)

Teoh H, Quan A, Leung SW \& Man RY $2000 b$ Differential effects of $17 \beta$-estradiol and testosterone on the contractile responses of porcine coronary arteries. British Journal of Pharmacology 129 1301-1308. (doi:10.1038/sj.bjp.0703164)

Tep-areenan P, Kendall DA \& Randall MD 2002 Testosterone-induced vasorelaxation in the rat mesenteric arterial bed is mediated predominantly via potassium channels. British Journal of Pharmacology 135 735-740. (doi:10.1038/sj.bjp.0704522)
Thompson PD, Cullinane EM, Sady SP, Chenevert C, Saritelli AL, Sady MA \& Herbert PN 1989 Contrasting effects of testosterone and stanozolol on serum lipoprotein levels. JAMA 261 65-71.

Toot JD, Reho JJ, Ramirez RJ, Novak J \& Ely DL 2012 Alterations in vasomotor systems and mechanics of resistance-sized mesenteric arteries from SHR and WKY male rats following in vivo testosterone manipulation. Biology of Sex Differences 3 1. (doi:10.1186/20426410-3-1)

Traish AM, Park K, Dhir V, Kim NN, Moreland RB \& Goldstein I 1999 Effects of castration and androgen replacement on erectile function in a rabbit model. Endocrinology 140 1861-1868. (doi:10.1210/en.140.4.1861)

Unemoto T, Matsushita M, Tamura K, Tanaka Y, Koike K \& Kogo H 2007 Role of BK channels in testosterone-induced relaxation of the aorta in spontaneously hypertensive rats. Biological \& Pharmaceutical Bulletin 30 1477-1480. (doi:10.1248/bpb.30.1477)

Vignozzi L, Cellai I, Santi R, Lombardelli L, Morelli A, Comeglio P, Filippi S, Logiodice F, Carini M, Nesi G et al. 2012 Antiinflammatory effect of androgen receptor activation in human benign prostatic hyperplasia cells. Journal of Endocrinology 214 31-43. (doi:10.1530/ JOE-12-0142)

Vikan T, Schirmer H, Njølstad I \& Svartberg J 2009 Endogenous sex hormones and the prospective association with cardiovascular disease and mortality in men: the Tromsø Study. European Journal of Endocrinology 161 435-442. (doi:10.1530/EJE-09-0284)

Walker TC 1942 Use of testosterone propionate and estrogenic substance in treatment of essential hypertension, angina pectoris, and peripheral vascular disease. Journal of Clinical Endocrinology and Metabolism 2 560-568. (doi:10.1210/jcem-2-9-560)

Wang C, Cunningham G, Dobs A, Iranmanesh A, Matsumoto AM, Snyder PJ, Weber T, Berman N, Hull L \& Swerdloff RS 2004 Long-term testosterone gel (AndroGel) treatment maintains beneficial effects on sexual function and mood, lean and fat mass, and bone mineral density in hypogonadal men. Journal of Clinical Endocrinology and Metabolism 89 2085-2098. (doi:10.1210/jc.2003-032006)

Webb CM, Adamson DL, de Zeigler D \& Collins P 1999a Effect of acute testosterone on myocardial ischemia in men with coronary artery disease. American Journal of Cardiology 83 437-439. (doi:10.1016/S00029149(98)00880-7)

Webb CM, McNeill JG, Hayward CS, de Zeigler D \& Collins P 1999b Effects of testosterone on coronary vasomotor regulation in men with coronary heart disease. Circulation 100 1690-1696. (doi:10.1161/01. CIR.100.16.1690)

White RE, Owen MP \& Stallone JN 2007 Testosterone-induced vasorelaxation of rat mesenteric microvasculature is $\mathrm{K}^{+}$channel- and nitric oxide-dependent but estrogen-independent (abstract). FASEB Journal 97210.

Williams MR, Ling S, Dawood T, Hashimura K, Dai A, Li H, Liu JP, Funder JW, Sudhir K \& Komesaroff PA 2002 Dehydroepiandrosterone inhibits human vascular smooth muscle cell proliferation independent of ARs and ERs. Journal of Clinical Endocrinology and Metabolism 87 176-181. (doi:10.1210/jc.87.1.176)

Wu FC \& von Eckardstein A 2003 Androgens and coronary artery disease. Endocrine Reviews 24 183-217. (doi:10.1210/er.2001-0025)

Wu SZ \& Weng XZ 1993 Therapeutic effects of an androgenic preparation on myocardial ischemia and cardiac function in 62 elderly male coronary heart disease patients. Chinese Medical Journal 106 415-418.

Xing D, Feng W, Miller AP, Weathington NM, Chen YF, Novak L, Blalock JE \& Oparil S 2007 Estrogen modulates TNF- $\alpha$-induced inflammatory responses in rat aortic smooth muscle cells through estrogen receptor- $\beta$ activation. American Journal of Physiology. Heart and Circulatory Physiology 292 H2607-H2612. (doi:10.1152/ajpheart. 01107.2006)

Yamada K, Hayashi T, Kuzuya M, Naito M, Asai K \& Iguchi A 1996 Physiological concentration of $17 \beta$-estradiol inhibits chemotaxis of human monocytes in response to monocyte chemotactic protein 1 . Artery 22 24-35. 
Yang YM, Lv XY, Huang WD, Xu ZR \& Wu LJ 2005 Study of androgen and atherosclerosis in old-age male. Journal of Zhejiang University. Science. B 6 931-935. (doi:10.1631/jzus.2005.B1206)

Yassin AA \& Saad F 2008 Testosterone and erectile dysfunction. Journal of Andrology 29 593-604. (doi:10.2164/jandrol.107.004630)

Yildirim E \& Erol K 2011 The effects of testosterone on isolated sheep coronary artery. Anadolu Kardiyoloji Dergisi 11 343-350.

Yildiz O, Seyrek M, Gul H, Un I, Yildirim V, Ozal E, Uzun M \& Bolu E 2005 Testosterone relaxes human internal mammary artery in vitro. Journal of Cardiovascular Pharmacology 45 580-585. (doi:10.1097/01.fjc. $0000161400.06704 .1 \mathrm{e}$

Yu J, Akishita M, Eto M, Ogawa S, Son BK, Kato S, Ouchi Y \& Okabe T 2010 Androgen receptor-dependent activation of endothelial nitric oxide synthase in vascular endothelial cells: role of phosphatidylinositol 3-kinase/akt pathway. Endocrinology 151 1822-1828. (doi:10.1210/en. 2009-1048)

Yue P, Chatterjee K, Beale C, Poole-Wilson PA \& Collins P 1995 Testosterone relaxes rabbit coronary arteries and aorta. Circulation 91 1154-1160. (doi:10.1161/01.CIR.91.4.1154)

Zhang X, Wang L, Jiang T, Zhang H, Dou Y, Zhao J, Zhao H, Qiao Z \& Qiao J 2002 Effects of testosterone and 17- $\beta$-estradiol on TNF- $\alpha$-induced
E-selectin and VCAM-1 expression in endothelial cells: Analysis of the underlying receptor pathways. Life Sciences 71 15-29. (doi:10.1016/ S0024-3205(02)01567-9)

Zitzmann M, Brune M, Kornmann B, Gromoll J, von Eckardstein S, von Eckardstein A \& Nieschlag E 2001 The CAG repeat polymorphism in the AR gene affects high density lipoprotein cholesterol and arterial vasoreactivity. Journal of Clinical Endocrinology and Metabolism $\mathbf{8 6}$ 4867-4873. (doi:10.1210/jc.86.10.4867)

Zitzmann M, Brune M \& Nieschlag E 2002 Vascular reactivity in hypogonadal men is reduced by androgen substitution. Journal of Clinical Endocrinology and Metabolism 87 5030-5037. (doi:10.1210/ jc.2002-020504)

Zitzmann M, Vorona E, Wenk M, Saad F \& Nieschlag E 2009 Testosterone administration decreases carotid artery intima media thickness as a marker of impaired vascular integrity in middle-aged overweight men. Journal of Men's Health 6243.

Zuloaga KL \& Gonzales RJ 2011 Dihydrotestosterone attenuates hypoxia inducible factor- $1 \alpha$ and cyclooxygenase- 2 in cerebral arteries during hypoxia or hypoxia with glucose deprivation. American Journal of Physiology. Heart and Circulatory Physiology 301 H1882-H1890. (doi:10.1152/ajpheart.00446.2011)

Received in final form 25 March 2013

Accepted 2 April 2013

Accepted Preprint published online 2 April 2013
C 2013 Society for Endocrinology Printed in Great Britain
Published by Bioscientifica Ltd. 